
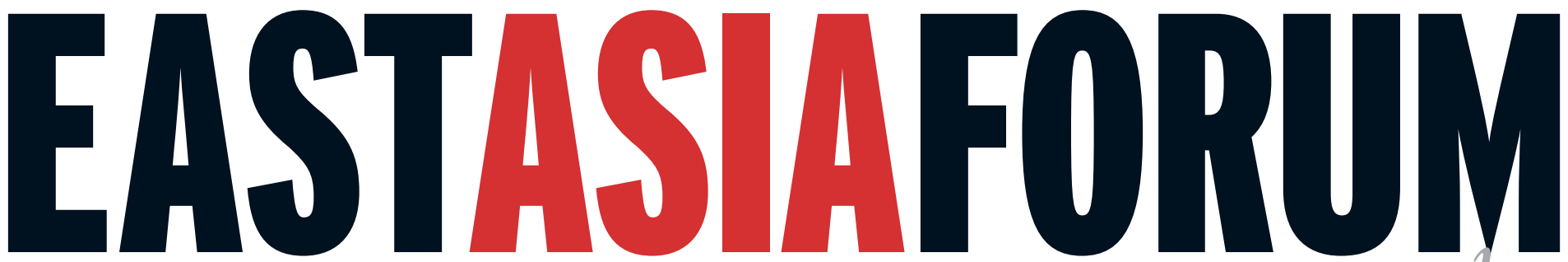

ECONOMICS, POLITICS AND PUBLIC POLICY IN EAST ASIA AND THE PACIFIC

Vol.11 No.4 October-December $2019 \$ 9.50$
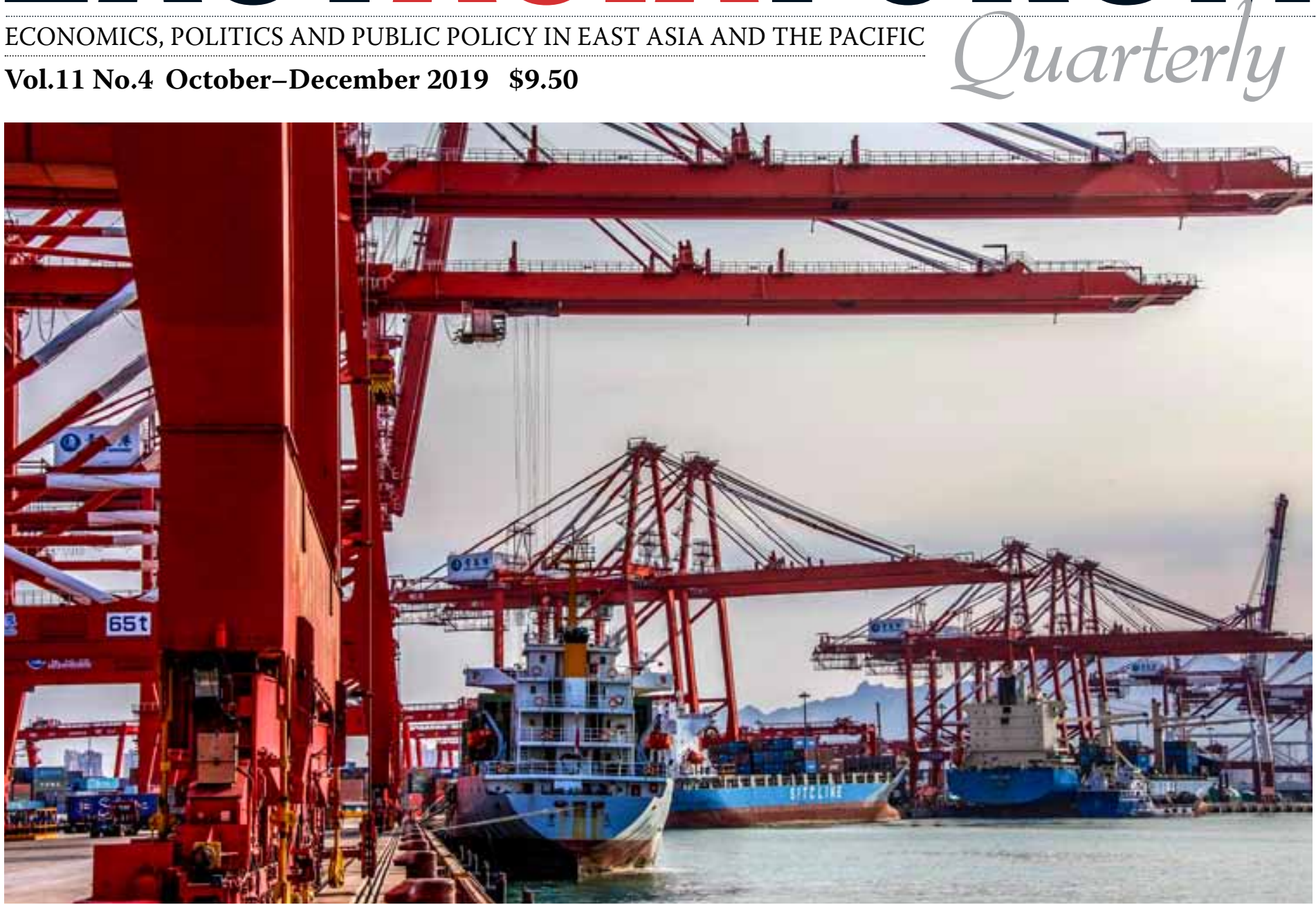

\title{
Economics and security
}

Rizal Sukma Indonesia, ASEAN and the Indo-Pacific idea

Chung-in Moon Breaking the North Korean nuclear stalemate

Peter Drysdale and Mari Pangestu Political security from economic security

Amy King Economics overrides China-Japan tensions ... and more

\section{ASIAN REVIEW}

Xiaoyan Lei and Chen Bai: China's ageing population challenge

Burhanuddin Muhtadi: Jokowi between political cartels and public interest 


\section{EASTASIAFORUM \\ . \\ ISSN 1837-5081 (print) \\ From the Editor's Desk \\ ISSN 1837-509X (online)}

The idea that countries can pursue prosperity and security as separate streams of the national interest has passed. Economics and security have always been enmeshed, although we assumed otherwise. The nature of the relationship between the two is changing fast. The narratives that surround the change find it difficult to keep up with the facts.

The world has become more multipolar, with remarkable growth outside the established powers in the North Atlantic. And big countriesnot just the United States and China but other G20 members like Brazil, Turkey, Russia and the United Kingdom-have become more nationalist and brazen in asserting what they perceive to be their economic and security interests over those of others. The US-China relationship is increasingly characterised by strategic competition in both the economic and security domains.

At the same time, digital technology has not just transformed products, firms and markets but it has opened them to cyber disruption and attack, resulting in a cross-over of security into the economic and social domains.

This issue of the East Asia Forum Quarterly explores what is happening, why, and how to respond to the change. These essays argue for careful thought and active engagement by governments, business and the broader community. Genuine dialogue and problem solving between the economic and security parts of universities and government is a good first step to frame the problem broadly, keep perspective, and find solutions.

The papers here argue that elements of practical handling strategies to achieve both prosperity and security include focusing on relationships that build knowledge and trust. The objective should be to strengthen domestic and international institutions and governance, as well as to build coalitions between government, business and communities, and internationally between powers both large and small with common interests, to reinforce the overriding imperative to resolve conflict and difference. The experience of economic and political cooperation in Asia may offer insight into how to navigate a new diplomacy.

Securitising economic and social interaction is not a viable path. Ultimately, even smaller and middle powers do not have to accept passively the changing status quo but can, with others, influence and moderate it and seek alternative paths.

In Asian Review, the massive problems associated with China's ageing, the politics of Jokowi's second term in Indonesia, and how the Iran problem plays into Asia are the subject of in-depth analysis.

\section{Gordon de Brouwer}

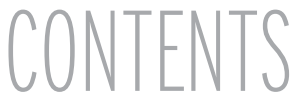

\section{GORDON DE BROUWER}

Risk management when security, economics collide

\section{JACOB TAYLOR}

Reimagining the China story in strategic thought

\section{PETER DRYSDALE AND \\ MARI PANGESTU}

Leveraging political security from economic security

11 RIZAL SUKMA

Indonesia, ASEAN, and shaping the Indo-Pacific idea

13 SIMON TAY AND JESSICA WAU ASEAN in the US-China contest

\section{BRENDAN SARGEANT}

Integrating Australia's security and economic policy cultures

17 BURHANUDDIN MUHTADI

ASIAN REVIEW: Caught between political cartels and public interest

22 XIAOYAN LEI AND CHEN BAI ASIAN REVIEW: Meeting the challenge of China's ageing population

26 MOHAMMAD SOLTANINEJAD ASIAN REVIEW: Iran turns to China and India in the face of US sanctions

28 MICHA'EL TANCHUM

ASIAN REVIEW: Iran and the

China-Russia pivot in Eurasia

31 DARREN J. LIM

Economic statecraft and the revenge of the state

\section{AMY KING}

Why China-Japan economic exchanges override tensions

35 PICHAMON YEOPHANTONG

Is China a rogue investor?

\section{KRISTIN VEKASI}

Weaponised interdependence and Japan's private sector

40 KAZUTO SUZUKI

Japan-ROK dispute: weaponsing trade?

42 CHUNG-IN MOON

Breaking the North Korean nuclear stalemate 


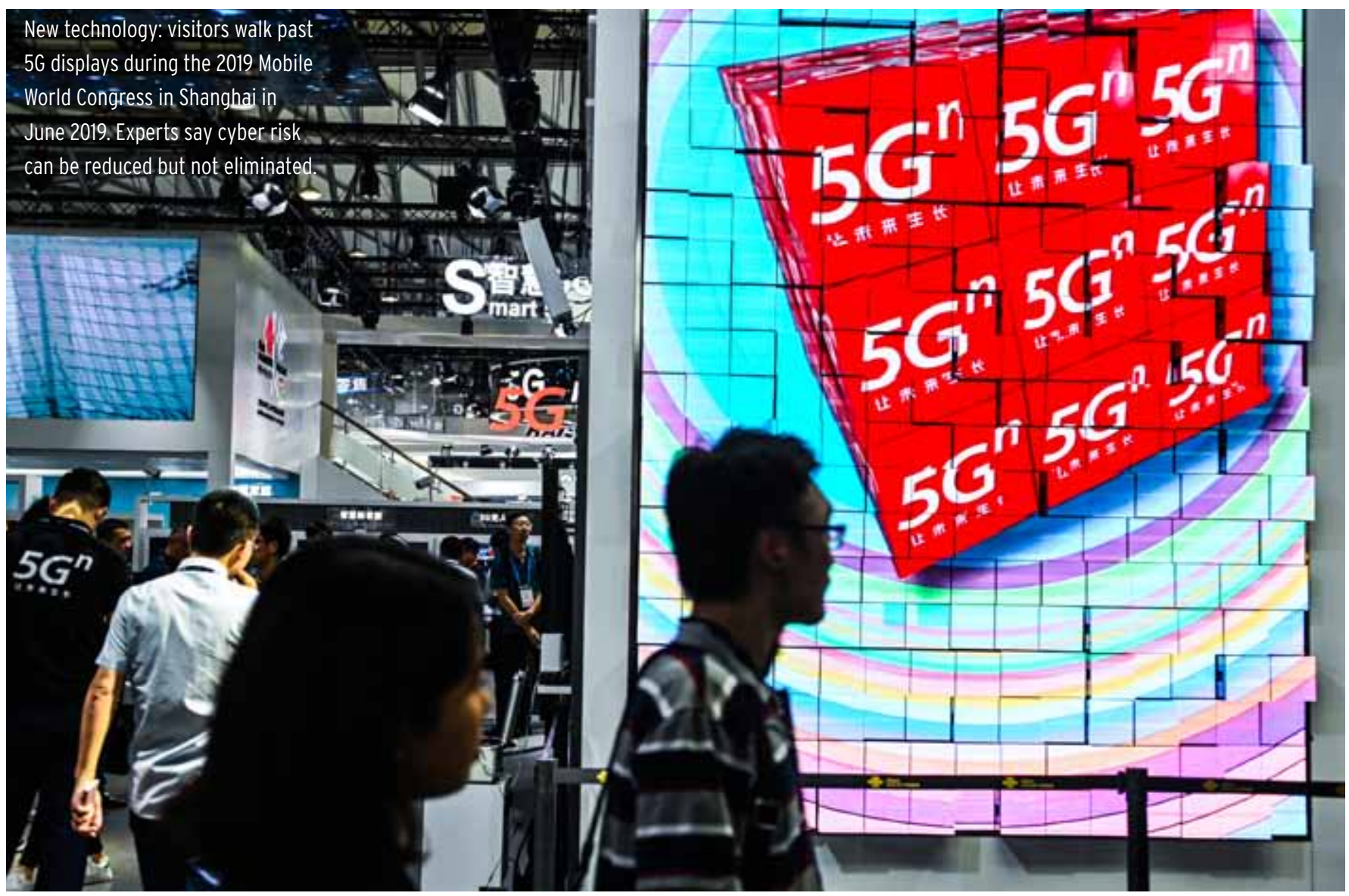

\section{Risk management when security, economics collide}

\section{GORDON DE BROUWER}

F OR over a generation, economics and security have been viewed as essential but largely separate elements of national interest. Two global developments have changed this: nationalist multipolarity and digitisation. The world has become more multipolar, with major powers increasingly willing to assert their security and economic interests unilaterally. The US-China relationship is characterised by growing strategic competition in both the security and economic domains.

Meanwhile digital technology, including quantum computing, machine learning and $5 \mathrm{G}$, is radically transforming most domains of human activity-from the way people interact with each other and obtain information and learn, to goods and services and the way firms and markets operate, to defence and security. The extensive and increasing digitisation of economic and social interactions has left states vulnerable to cyber intrusion and attack by both state and non-state actors.
Two principles can help countries frame thinking about the interaction between economics and security.

First, thinking needs to be framed from the start in terms of the three components of national interestprosperity, security and social harmony. All three matter. And more than ever they reinforce each other. Security underpins prosperity, prosperity pays for power and security, and social harmony reduces economic and security risks.

Second, analysis needs to explain risks to the national interest and 


\section{EASTASIAFORUM Ouarterly EDITORIAL STAFF}

Issue Editor

Gordon de Brouwer is Honorary Professor at the ANU College of Asia and the Pacific and was formerly the Secretary of the Australian Department of the Environment and Energy.

\section{Series Editors}

Peter Drysdale, Head, East Asia Forum and East Asian Bureau of Economic Research, Crawford School of Public Policy, ANU.

Shiro Armstrong, Director, AustraliaJapan Research Centre, and Editor, East Asia Forum, Crawford School of Public Policy, ANU.

\section{Editorial Staff}

Coordination: Marie Armstrong. Editing: Benjamin Clarke, Alison Darby, Oliver Friedmann, Annie Gao, Illiana Jain, Jade Lin, Dorothy Mason, Arun Murali, Maya Salama, David Wu, Catherine Yen, ANU.

Editorial Advisers: Peter Fuller, Max Suich.

Production: Peter Fuller, Words \& Pics.

Email Peter.Drysdale@anu.edu.au, Shiro.Armstrong@anu.edu.au.

COVER: Loading freight at Qingdao, Shandong province, China. PICTURE: Reuters.

Views expressed are those of individual authors and do not represent the views of the Crawford School, ANU, EABER, EAF, or the institutions to which the authors are attached.

\section{ANU PRESS}

Published by ANU Press The Australian National University Canberra ACT 2601, Australia

Email: anupress@anu.edu.au Web: http://press.anu.edu.au identify practical ways to mitigate them. Risks often affect both security and prosperity. And the mitigations can be found by thinking beyond a single domain. As a general proposition, it is in a country's interest that countries that pose a security risk to it have other strong interests to balance, effectively raising the cost of conflict and creating an incentive to find an enduring solution.

Mitigations to a security risk might lie in economic or social domains. For example, strengthening domestic governance, market systems and people-to-people connections (through migration, tourism and international education) support cooperation rather than confrontation.

Defence and security are public goods typically provided by governments. Risk mitigation, in contrast, need not always be directly provided by governments. The actions of other parts of society-especially business and civil society—can help mitigate risk over time. In this sense, the responsibility of government is to enable and create incentives for others to mitigate risks. This is typically achieved by strong domestic laws, markets and governance institutions supported by effective monitoring, compliance and enforcement.

Scenario analysis with a wide range of participants is another useful way to frame risk and look for solutions, as is done in Singapore. These exercises bring insights into the global interplay of forces in the domains of the economy (technological change and the impact of data and digitisation), security (the multipolar order, nonconforming nations and proliferation) and society (trust in institutions, belonging and social media). This analytical framework challenges conventional habits of thinking and supports integrated strategic thinking.
The standard toolkit

\section{of international and}

\section{development economics}

can help allay security

\section{concerns}

Take three examples.

Consider, first, the concern that China is using the Belt and Road Initiative as a strategic play to gain leverage over governments and acquire critical infrastructure, especially in cases when countries cannot repay debt. How should a recipient country address this? Simply refusing foreign investment deprives the country of what might be economic and social infrastructure important for its prosperity. It also deprives China of an opportunity to support others' development commensurate with its economic size and power.

All donor countries use aid and financial assistance as a tool of foreign policy, so the interest of the recipient country is best served by engaging with a variety of donors and organisations so that it is not hostage to dependence on a single large donor. Meanwhile strong governance-including objective economic and social cost-benefit analysis, competitive, open and non-discriminatory bidding, and independent dispute resolution-are essential tools to secure the benefits of the investment. The standard toolkit of international and development economics can help allay security concerns.

Another example of risk is 
foreign investment in digital and telecommunications infrastructure. The first step is to identify and assess risk. The primary digital security risk is a cyber-attack by malicious state or non-state actors that disables key digital and telecommunications infrastructure. Foreign investment rules focus on ownership, but ownership is not the fulcrum of risk. It is widely judged that cyber risk can be reduced but not eliminated. Risk mitigation includes strong defences in firms and organisations against cyberattacks and enforcement of strong laws against cyber-attacks.

Market structure matters for risk mitigation. The more participants and the more diverse the structure of the market, the lower the risk associated with any one firm. From this perspective, policies to encourage product innovation and the creation of new firms, along with policies and laws to protect market contestability, can help mitigate security risks. The debate about foreign ownership of $5 \mathrm{G}$ networks might be different if the sector was competitive and diverse, rather than concentrated in a small number of highly integrated firms.

Risk associated with digital technology depends on whether potential cyber-attacks are conducted by large state actors. Analogous to the nuclear arms race, the cyber capabilities of the major powers have reached the stage where a cyber-attack by one would likely lead to a cyberattack by another. Mutually assured digital destruction (MADD) changes the risk of cyber-attacks between the major powers and their allies outside of explicit war.

A final example of risk is data. There are concerns that international firms may be particularly susceptible to theft of personal data, including information about a person's health, finances or behaviour. Again, cyber- attacks are the core risk. Primary risk mitigation properly focuses on the cyber defences of firms, supported by the enforcement of strong laws around corporate transparency and the protection of privacy, and resilience when breaches occur.

The world has changed, and the challenge is to draw on the full toolkit to assess risk clearly and mitigate risk creatively and strategically. It is time for countries to engage rather than withdraw. They should work together and engage directly with the United States and China on practical and mutually beneficial steps to mitigate, rather than exacerbate, US-China strategic competition. EAFQ

\section{Gordon de Brouwer is Honorary} Professor at the ANU College of Asia and the Pacific and was formerly the Secretary of the Australian Department of the Environment and Energy.

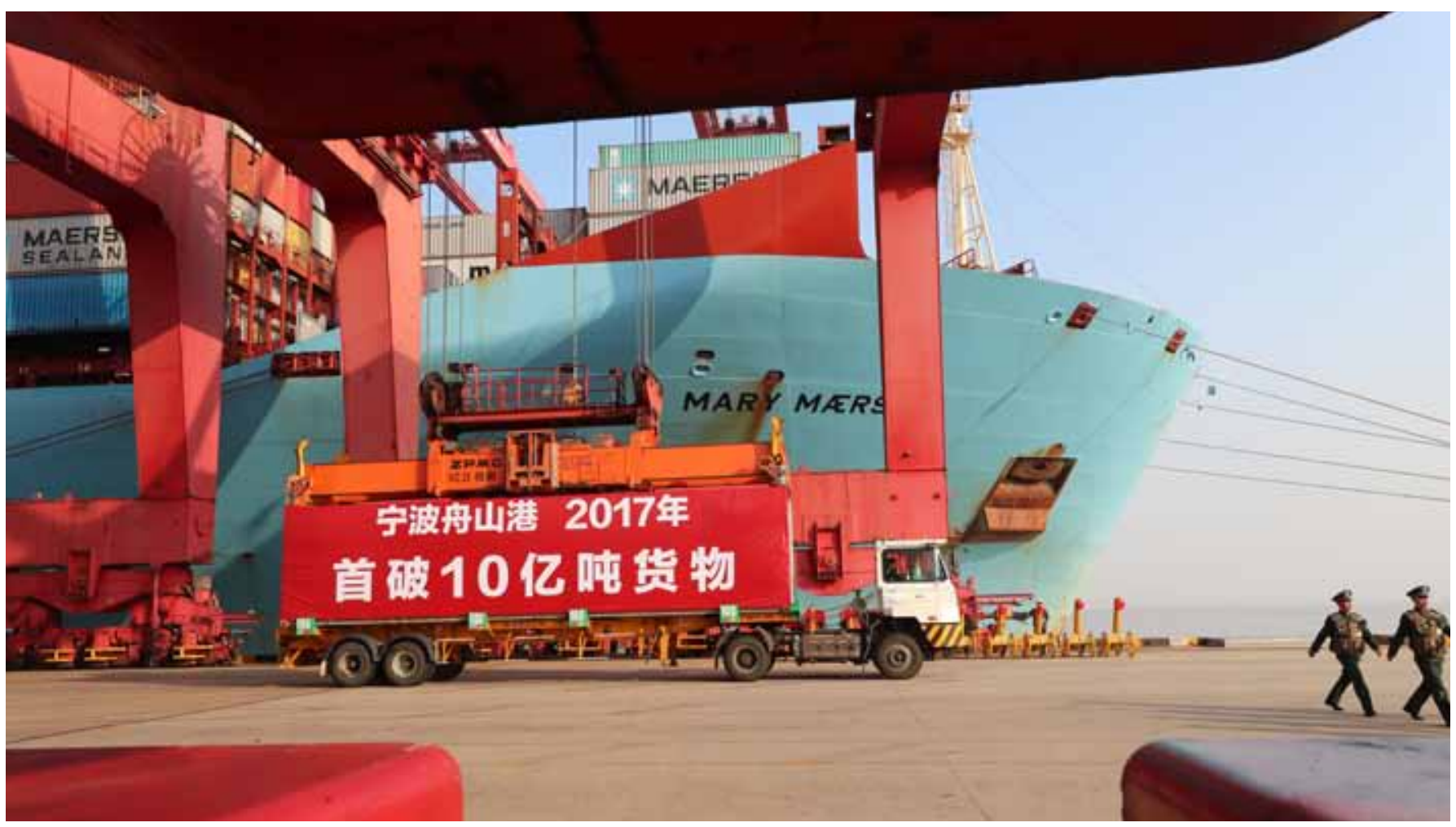

Loading cargo at Ningbo-Zhoushan in China's Zhejiang province. Part of the Maritime Silk Road, the port has links to more than 600 international destinations. PICTURE: YI MINGZHAN / IMAGINE CHINA / REUTERS 


\section{Reimagining the China story in strategic thought}

JACOB TAYLOR

NTERNATIONAL strategic

thinking appears to have evolved into a clear-headed process of balancing national economic and security interests while deemphasising more subjective narratives like national or global values. But there are big questions about reconciling economic and security interests in a comprehensive national strategic framework. The economic-security nexus may not be all that is needed for sophisticated analysis of our geopolitical terrain.

What is missing in the existing formula for international relations if indeed nations like the United States and China appear to be so prone to misapprehending each other's motivations and actions?

From the viewpoint of brain and behavioural sciences, clearly what is missing is recognition that implicit narratives subconsciously pervade explicit strategic thought, even when analysis is consciously restricted to cold, hard interests.

It could be said that the US-led strategy of comprehensive economic and diplomatic engagement with China was sustained in Washington by an implicit narrative that Beijing's entry into international markets would eventually drive democratic political reform, making China more like the United States. Indeed, some would argue, deep down Washington may have believed it could play a particular role in China's political liberalisation.
In the same vein, Washington's current view of China as a strategic competitor is underpinned by an implicit narrative that China's rise threatens America's place in the world order. The 'China as threat' narrative interprets the Chinese Communist Party's (CCP) pervasive yet opaque influence in all areas of China's activity at home and abroad as evidence of a coordinated system of control that threatens US interests.

When boiled down, each explicit strategic appraisal of China is also constrained and propelled by an implicit mythology about the Self ('the United States as liberal champion') or the Other ('China as nefarious threat').

Confining international strategic thinking to security and economic interests is unlikely to stop subjective

The narratives that

underwrite US-led

economic and security

appraisals of China

implicitly define the

international arena as a

two-dimensional game

between monolithic

national actors narratives from implicitly shaping and directing strategic thought.

Over time, science has shown that the human mind is more storyteller than factual analyst. The mind filters information to support coherent narratives about the world, and it is less attuned to evidence than it is to the persuasiveness of characters who deliver it. These facts once justified the view in international strategic thinking that quantifiable interests should take precedence over values, usually couched in anecdotal and emotive narratives. But frontier research in neuroscience and psychology now demonstrates that narratives are not so easily abandoned when thinking strategically. Narratives do not merely exist 'out there' in the world but are physically embodied in concrete patterns of neuronal, emotional and psychological activity.

The stories that we tell about ourselves play a fundamental role in defining the possibilities and limits of thought and action.

Deep mythologies, therefore, are likely to structure the way that nations coordinate (or conflict) with each other. The narratives that underwrite US-led economic and security appraisals of China implicitly define the international arena as a two-dimensional game between monolithic national actors. The only imaginable outcome of such a game is that one nation must prevail over the other through direct mechanisms of coercion and control.

By downplaying the function of 


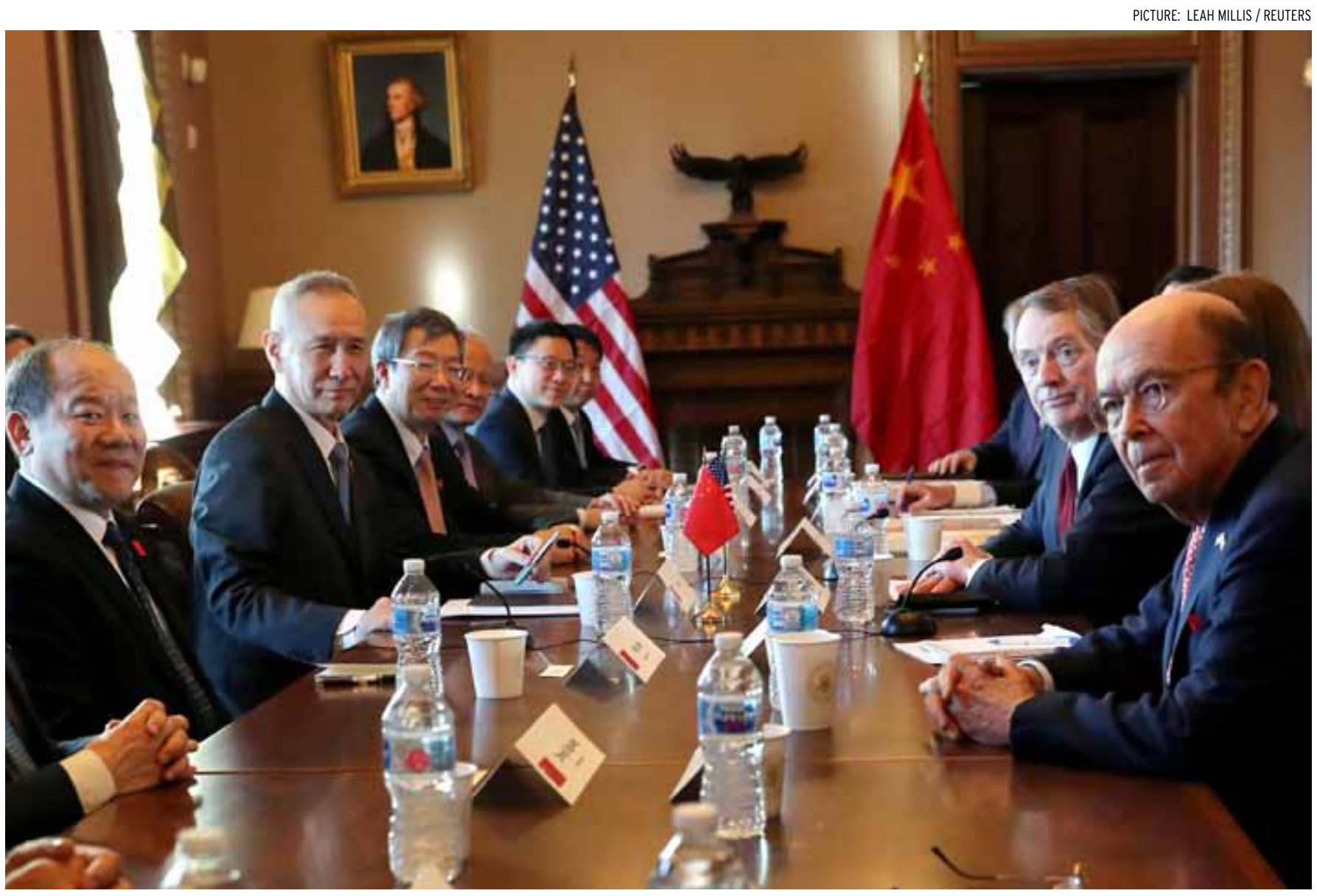

Playing games? Negotiating teams led by China's Vice-Premier Liu He and US Trade Representative Robert Lighthizer at the White House in January 2019.

narrative in policy development, a security-economic nexus of interests in international strategic thinking might deprive itself of the vital information required to envisage more sophisticated and multidimensional scenarios for shared security and prosperity.

The narrative underpinning the China-as-threat view, for example, inhibits analysis of evidence that the CCP is a decentralised and politically contested system of relationships. It also precludes consideration of the way economic engagement can function as an instrument of security-economic interdependence with China pluralises and constrains its interests and, therefore, mitigates security risks.

The narrative that democratic political reform will inevitably follow economic liberalisation in China ignores the way that political and cultural processes intersect with economic incentives to drive social change. This narrative inhibits an agnostic and open-ended analysis of China's economic and political transformation, including the potential security risks that such a transformation might pose to US international interests.

In each case, the security policy tribe's strategy is never quite in line with that held by the economic policy tribe. Neither strategy offers sufficient scope for comprehending the multidimensionality of the geopolitical terrain.

If not addressed, it is likely that the missing narrative dimension in international strategic thought will sustain decisions that are at best inefficient, or at worst catastrophicincreasing the risk of military conflict, financial crises or irreversible environmental degradation.

The key question is what research is needed to comprehend the role of narratives in shaping international strategic thought.

An emerging 'neuroscience of narrative' could be enlisted to establish causal links between deepseated national mythologies and the patterns of neuronal, emotional and psychological activity that such narratives afford. Theory and methods from 'cultural evolution' could also be used to trace the production and proliferation of these narratives within national systems and their 
relationship to strategic thinking and the development of foreign policy. And qualitative and quantitative social scientific research could be brought to bear on the question of how to evolve and reform international institutions in ways that allow for more sophisticated, complementary and sustainable interaction between nations.

Harvard University's Adam Breur and Alastair Johnston show how an interdisciplinary approach could work. They use theory and methods from cultural evolution to trace the development of the master narrative of 'China as a revisionist power' within specific networks of US foreign policy development and throughout the English-language digital media. They present evidence to suggest that simple, categorical and zero-sum subnarratives-such as 'China is a threat to the liberal order' and memes such as 'China challenges the rules-based order'-crowd out more nuanced but less emotionally compelling strategic assessments of the China-US relationship.

\section{'The United States is}

playing chess while

China is playing Go' is

now a common adage

to explain why these two

\section{countries appear prone}

to misapprehending each

\section{other's motivations}

This approach will help identify the mechanisms that drive foreign policy development and the dynamics of international cooperation and conflict. Analysing a specific policy in terms of the genealogy of its narrative components makes it possible to test the hypothesis that emotional and subjective factorsand not just explicit economic or security interests-shape and propel international strategic thinking. Ultimately, this approach could inform thinking about the types of collective narratives needed to underwrite shared security and prosperity within national and international institutions of governance. 'The United States is playing chess while China is playing Go' is now a common adage to explain why these two countries appear prone to misapprehending each other's motivations and actions on the international stage. For policymakers the real problem is that existing frameworks for international strategic thinking do not offer space to imagine more sophisticated games or, indeed, to consider whether nations should be playing games at all. EAFQ

Jacob Taylor is a Visiting Research Fellow at the East Asian Bureau of Economic Research at the Australian National University and a Postdoctoral Associate at the Institute of Cognitive and Evolutionary Anthropology at the University of Oxford. He specialises in coordination dynamics of social systems and China.

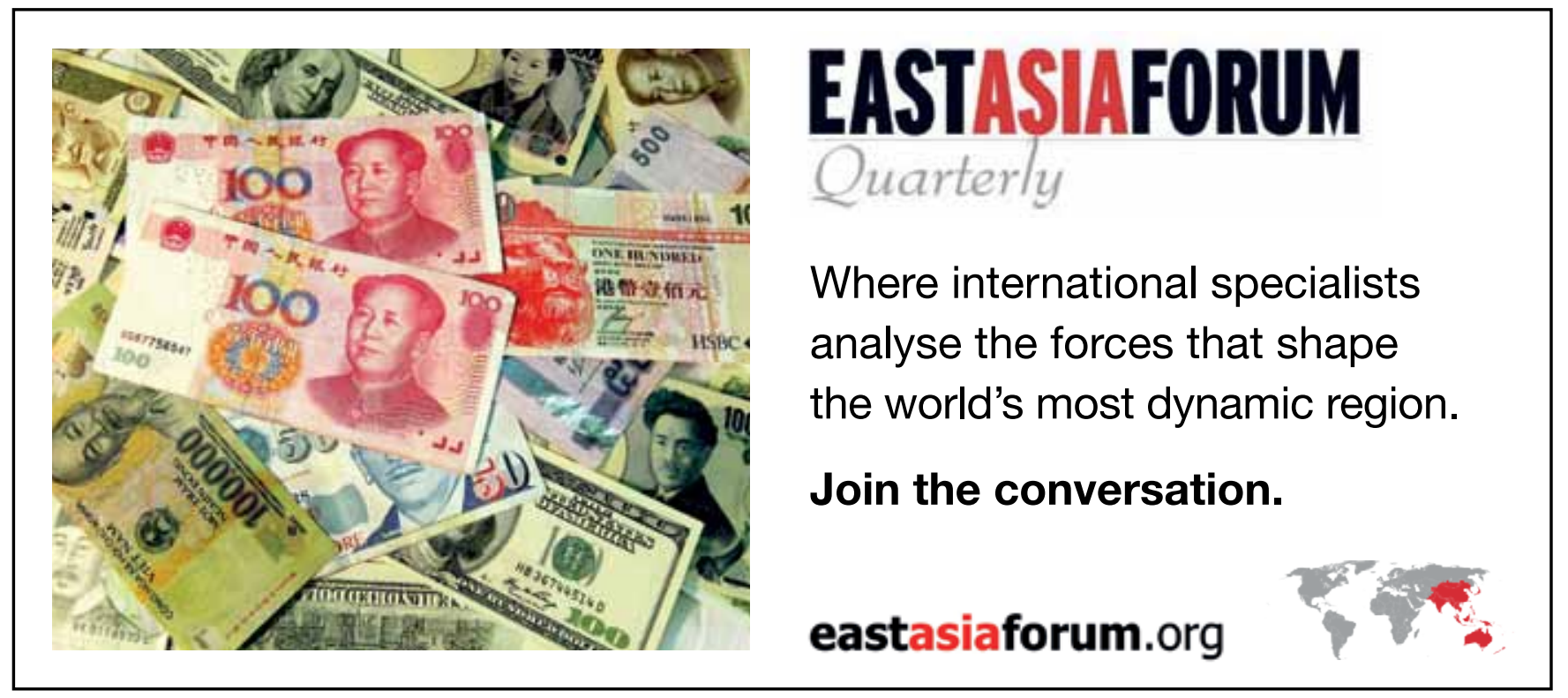

8 EAST ASIA FORUM QUARTERLY OCTOBER - DECEMBER 2019 


\section{Leveraging political security from economic security}

\author{
PETER DRYSDALE \\ AND \\ MARI PANGESTU
}

\section{A} SEAN cooperation arrangements and APEC are important international assets. They have contributed significantly to shared prosperity and political security in the Asia Pacific region by building pillars for trade liberalisation, investment, the movement of people and-most importantly-political certainty and trust. The political foundations of cooperation arrangements in East Asia and the Pacific were founded on shared ambitions for the economic development of the region's peoples and appreciation of their different levels of development.

These are underappreciated facts of importance to the theory of international diplomacy and its conduct in the chaos and uncertainty that dominate the global international outlook today.

In the 1960s, Swedish economist Gunnar Myrdal identified Southeast Asia as a region stuck in a vicious cycle of poverty, a likely sea of instability and woes for many years to come. Myrdal's prognosis for the region seems to have been spectacularly wrong, but to an observer of the region at the time it might have seemed a plausible and accurate story about the state of the Southeast Asia's emergent nations.

What changed all this was how the Southeast Asian economy was turned around-not all at once or at the same pace but in a common direction at

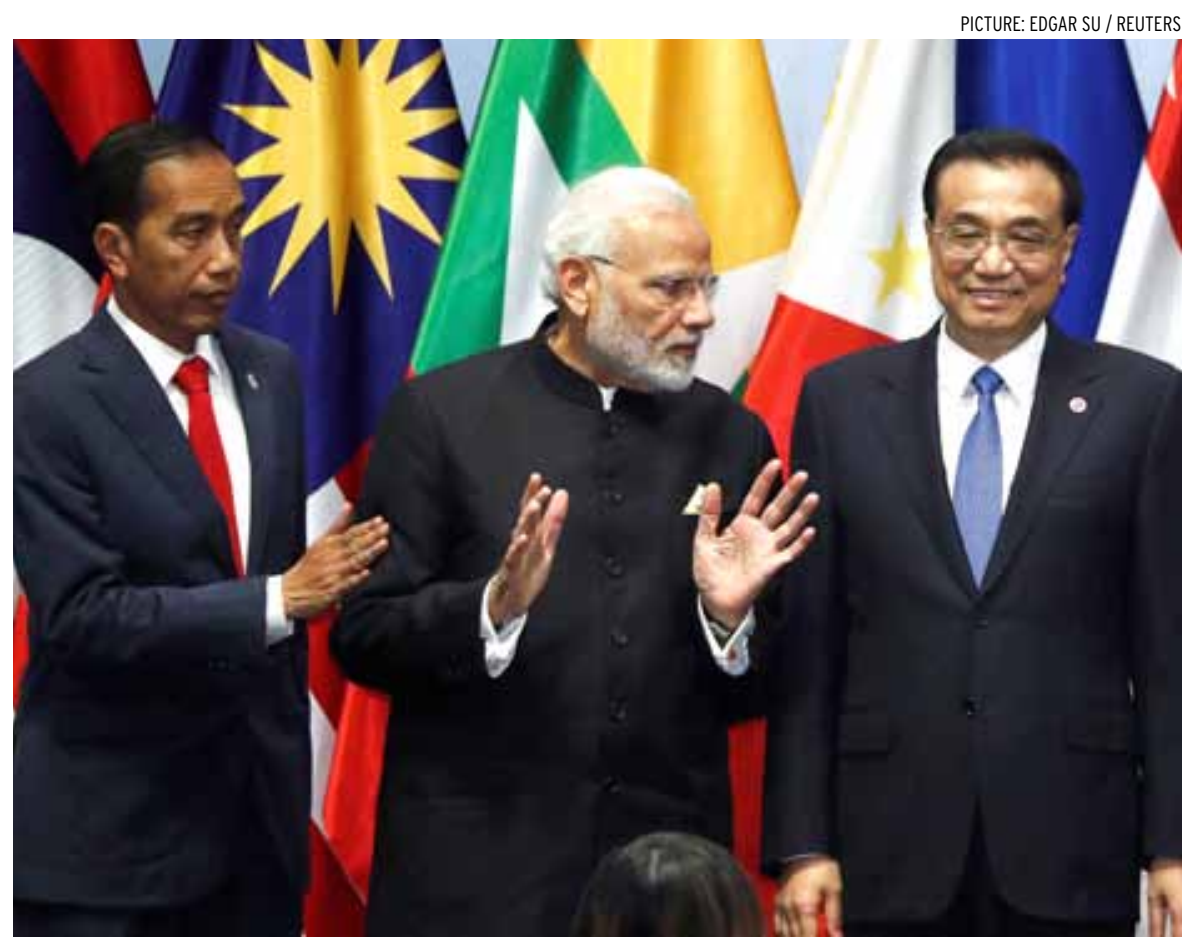

Indian Prime Minister Narendra Modi, centre, with Indonesia's President Joko Widodo and China's Premier Li Keqiang at the meeting of the Regional Comprehensive Economic Partnership (RCEP) in Singapore in November 2018. RCEP is 'an ASEAN conception of the regional order, not a Chinese initiative'.

around the same time. Without the redirection of economic policies across the region, ASEAN's innovation and success would hardly have become the lynchpin of East Asian political arrangements that it is today.

Regional cooperation arrangements such as APEC, the ASEAN Plus frameworks or the emergent Regional Comprehensive Economic Partnership (RCEP) are not hardwired institutionally into ASEAN. But all these regional cooperation frameworks in East Asia and the Pacific were born of the same parentage and are genetically inseparable from the principles and practices that have sustained ASEAN's economic and political success.

The diversity in stages of development, economic endowments, institutions, culture, religion and ethnicity may appear to have been an enduring source of regional political fragility. Economically, however, it was a fountain of strength that offered opportunities for specialisation that multiplied gains from trade for growth.

Growing economic security also attenuated the politics of ASEAN and Asian diversity and ensured its reach and influence, though at times this might have appeared tenuous; and it will be economic security and 
success that underpins Asia's political sway and effectiveness in the face of the great political uncertainties that confront the world and Asia today.

The APEC Bogor Goals of free and open trade by 2020 , adopted in 1994 , embodied a strategic commitment to the core pillars of economic openness. While completely free and open trade remains an aspiration in the region, the evidence is that APEC's continued commitment to openness has delivered substantial benefits to its members.

The global order has changed in ways that threaten the core pillars upon which Asia's economic cooperation system-ASEAN, APEC and the East Asian arrangementshave promoted shared prosperity and security. The change is a product of big shifts in the structure of global power, with the rise of China and other emerging economies now a cause of deep disquiet within the established powers.

The response to this and a withdrawal from globalisation are reflected in the surge in protectionism and retreat from multilateralism. This is exemplified in Europe by Brexit, by the Trump administration's 'America First' policies on trade and investment, by China's reciprocated response to US policies, and a raft of negative regional and bilateral action. Recent action in the Asia Pacific region, too-from the US-China trade and technology war to economic tensions between South Korea and Japan-make it clear that something is broken.

These conflicts and tradedestroying strategies either completely ignore or circumvent the established rules of engagement for international trade. While big gaps in these rules and new issues need to be dealt with, strategies that effectively tear down the established rules serve to corrode the
Although India was slow

to grasp the strategic

significance of RCEP it has

elevated early conclusion

of an ambitious RCEP as

a foundational element

in its quest for a new

multipolar global order

open multilateral order.

These developments are

undermining trade and investment flows, disrupting supply chains and causing long-term damage to the confidence and predictability that underpin cross-border commerce. The downturn in global foreign direct investment (it dropped 23 per cent in 2017 and 18 per cent in 2018) illustrates the impact of protectionism on the confidence and certainty that sustain strong economic activity.

For Southeast Asia, a region that has developed because of trade and in which cross-border trade is heavily tethered to cross-border investment, these developments are a signal that the situation is critical and that an urgent and concerted response is needed.

The global economic regime is in a time of crisis. Asia's central interest is to frame a dialogue and an action plan that deals with this crisis directly and resolves the tensions between protecting the global economic system and correcting the imbalances in that system.
RCEP is now vital in shaping Asia's and ASEAN's response to its new security circumstances. It encompasses China and India, the region's two big emerging powers. Although India was slow to grasp the strategic significance of RCEP it has elevated early conclusion of an ambitious RCEP as a foundational element in its quest for a new multipolar global order and an opportunity to embrace of the dynamism that defines Asia. Through all the twists and turns of RCEP's negotiation, when key ASEAN members leant towards leaving India behind, China and Japan did not waver from the strategic importance of keeping India in.

RCEP is an ASEAN conception of the regional order, not a Chinese initiative, as former US president Barack Obama once wrongly claimed. Like other ASEAN economic arrangements on which it is built, RCEP is not merely another free trade agreement. It is an economic cooperation arrangement and, like all ASEAN-centred economic cooperation arrangements in Asia, it is founded on political cooperation and underpins political security as a collateral but primary international public good.

Peter Drysdale is Emeritus Professor of Economics, Head of the Asian Bureau of Economic Research and Editorin-Chief of East Asia Forum in the Crawford School of Public Policy at the ANU.

Mari Pangestu is Professor of Economics at the University of Indonesia, head of the Indonesian Bureau of Economic Research, Senior Research at CSIS in Jakarta and formerly Indonesia's Minister of Trade and Tourism. 
RIZAL SUKMA

D URING the 34th ASEAN

Summit in Bangkok in June, the regional group's leaders officially endorsed and adopted the 'ASEAN Outlook on Indo-Pacific' (AOIP). They agreed, in light of the ongoing strategic changes in the region, that ASEAN needs its own vision for the future of regional order. Yet, as we enter the third decade of the 21st century, the strategic challenges facing ASEAN now are different from the past-and different challenges require different responses.

ASEAN hopes that a distinct vision will reconcile the competing visions of a regional order advocated by major powers. Adopting the Outlook will remind ASEAN and extra-regional powers of a simple message: ASEAN centrality should never be forgotten. Indeed, one of ASEAN's remarkable qualities since its inception in 1967 has been its ability to survive the power plays among great powers.

During the Cold War era ASEAN (only five members at the time) believed that it could preserve regional peace and stability by trying to keep great power rivalries out of the region. The Zone of Peace, Freedom and Neutrality (ZOPFAN) is a clear example of this approach.

When the Cold War ended, a new strategic context compelled ASEAN to open up and embrace extra-regional powers as a strategy for maintaining peace and stability in the region. This is demonstrated by the proliferation of ASEAN-centred multilateral processes and platforms such as the ASEAN Regional Forum (ARF), the ASEAN+3 (APT), the ASEAN Defense Ministers Meeting-Plus (ADMM-Plus) and the East Asia Summit (EAS).

This short-lived unipolar moment allowed ASEAN to focus more on deeper institutionalisation and the regional community-building project. ASEAN successfully adopted the ASEAN Charter and agreed on a blueprint to transform itself into an ASEAN Community.

Today, ASEAN finds itself in completely new terrain. The world is undergoing profound change. Scholars and policymakers speak of a world in disarray, disorder and even anarchy. Norms no longer define how states behave towards each other.

Faced with such strategic uncertainty, every nation is scrambling to situate itself in the emerging strategic environment, individually or collectively. Some of us in Indonesia have begun to worry about peace and stability in Southeast Asia, about the future of ASEAN, about the future of

ASEAN can no longer sit

and watch extra-regional

powers actively shape

the future of the region
East Asia and more importantly about Indonesia's place in the emerging regional order.

The geoeconomic and geopolitical centre of gravity is shifting from West to East. China is fast becoming a great power, if it is not already. The United States is trying to sustain its primacy in the world while dismantling the international order it helped build since 1945 . Yet the process of that strategic change is still unfolding, and its final outcome remains to be seen.

Three developments have emerged from that process of change. First, a great-power game is returning to Southeast Asia. Second, the future of Southeast Asia is increasingly defined by how extra-regional powers interact with each other. And third, key extra-regional powers are beginning to formulate and promote their own visions of regional order.

This raises two questions for the region. Are we about to see the end of the ASEAN-centred regional order? And if so, what are we going to do about it?

The ASEAN Outlook on IndoPacific is an attempt to provide answers to these questions. The AOIP recognises it is in the interest of ASEAN to lead the shaping of their economic and security architecture' in order to address challenges stemming from changes in the Asia-Pacific and Indian Ocean regions.

The Outlook promises that ASEAN will 'continue to maintain its central role in the evolving regional architecture in Southeast Asia and its surrounding regions' and continue 
to be 'an honest broker within the strategic environment of competing interests'

This is the key rationale behind Indonesia's Indo-Pacific proposal to ASEAN, a proposal which began when Foreign Minister Retno L. P. Marsudi gave a major policy speech on the issue on 16 May 2018.

Indonesia needs to ensure that the AOIP is not another exercise in norm-setting. President Jokowi is now trying to balance past preference for norm-setting and norm-building with more action-oriented, realistic and interest-driven initiatives in foreign policy. This points to two imperatives for Indonesia.

First, it is imperative for Indonesia to continue implementing its maritime strategy agenda comprehensively. Second, it is also imperative for Indonesia to continue driving the discussion within ASEAN on a common policy and strategy for navigating the Indo-Pacific.

The AOIP is a response to the growing external pressures that threaten ASEAN's unity, undermine ASEAN's relevance and corrode ASEAN's centrality. Responding to external change at critical times is something ASEAN has always been good at.

Seen in this light, the AOIP is a strategic necessity. ASEAN can no longer sit and watch extra-regional powers actively shape the future of the region. ASEAN must ensure that its two core interests-ASEAN centrality and strategic autonomy of the region-will be preserved, enhanced and reinforced. ASEAN hopes that the AOIP will provide the necessary platform to do that.

The AOIP would not have been possible without Indonesia's initiative and determination. Under the leadership and direct involvement of Foreign Minister Retno, Indonesia managed to convince its regional partners that it is a strategic necessity for ASEAN to articulate its own vision of the future regional order and its architecture.

Our key strategic interest in the region is to maintain ASEAN's strategic autonomy. Indonesia hopes and expects the AOIP to address strategic challenges in the region, give impetus for greater regional cooperation and serve as a platform through which great-power rivalries can be mitigated.

Indonesia also expects the AOIP to serve as an inclusive meeting place for the competing visions of regional order offered by great and regional players. And most importantly, it expects to maintain ASEAN's relevance, uphold ASEAN's centrality, preserve ASEAN's unity and sustain Southeast Asia's strategic autonomy.

EAFQ

\section{Rizal Sukma is Indonesia's Ambassador} to the United Kingdom, Ireland and the International Maritime Organization (IMO). This article was based on his presentation at the Centre for Strategic and International Studies (CSIS)

Lecture Series on Regional Dynamics in Jakarta on 28 August 2019.

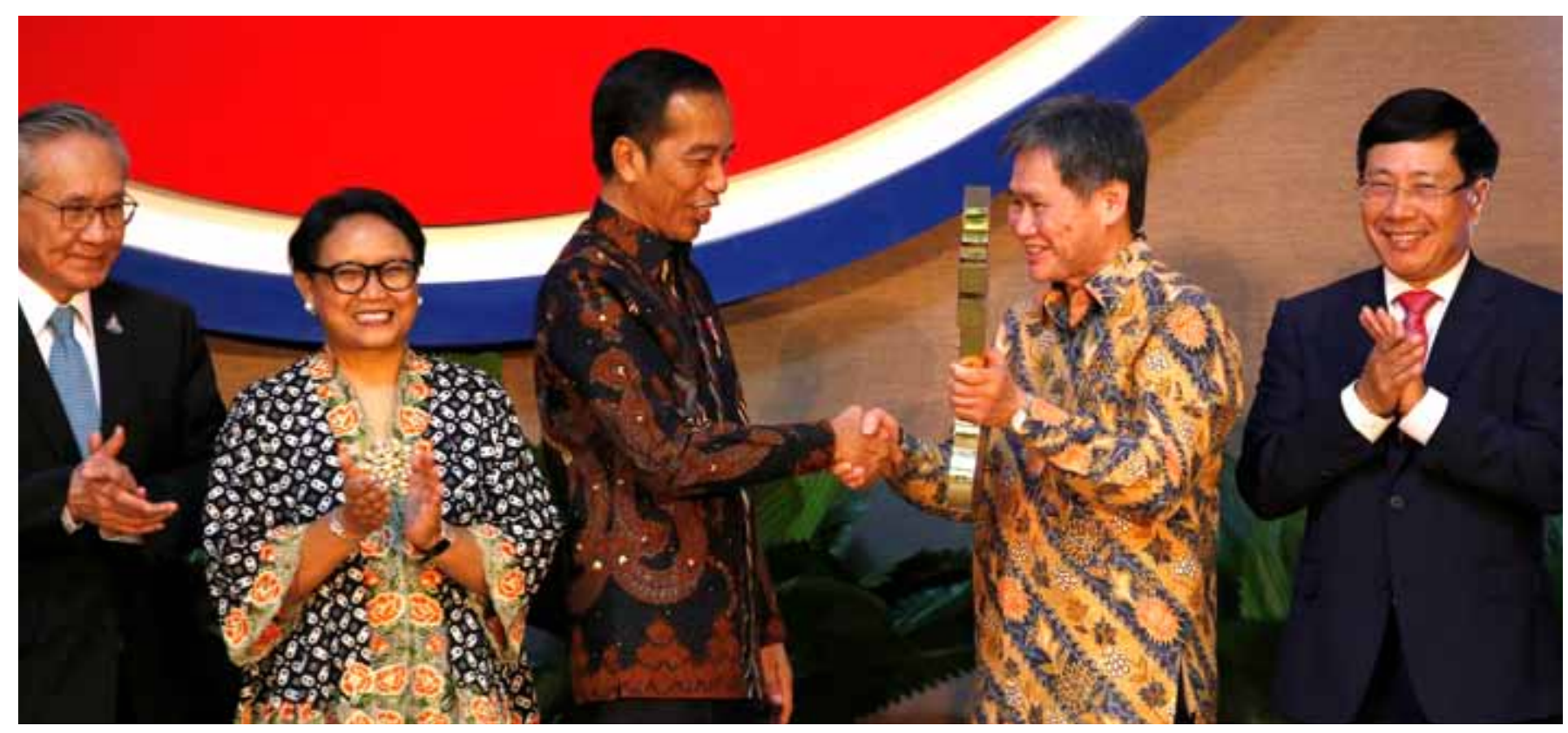

A symbol of 'deeper institutionalisation': Indonesian President Joko Widodo shakes hands with ASEAN Secretary-General Lim Jock Hoi at the inauguration of the new ASEAN Secretariat Building in Jakarta on 8 August 2019.

PICTURE: WILLY KURNIAWAN / REUTERS 


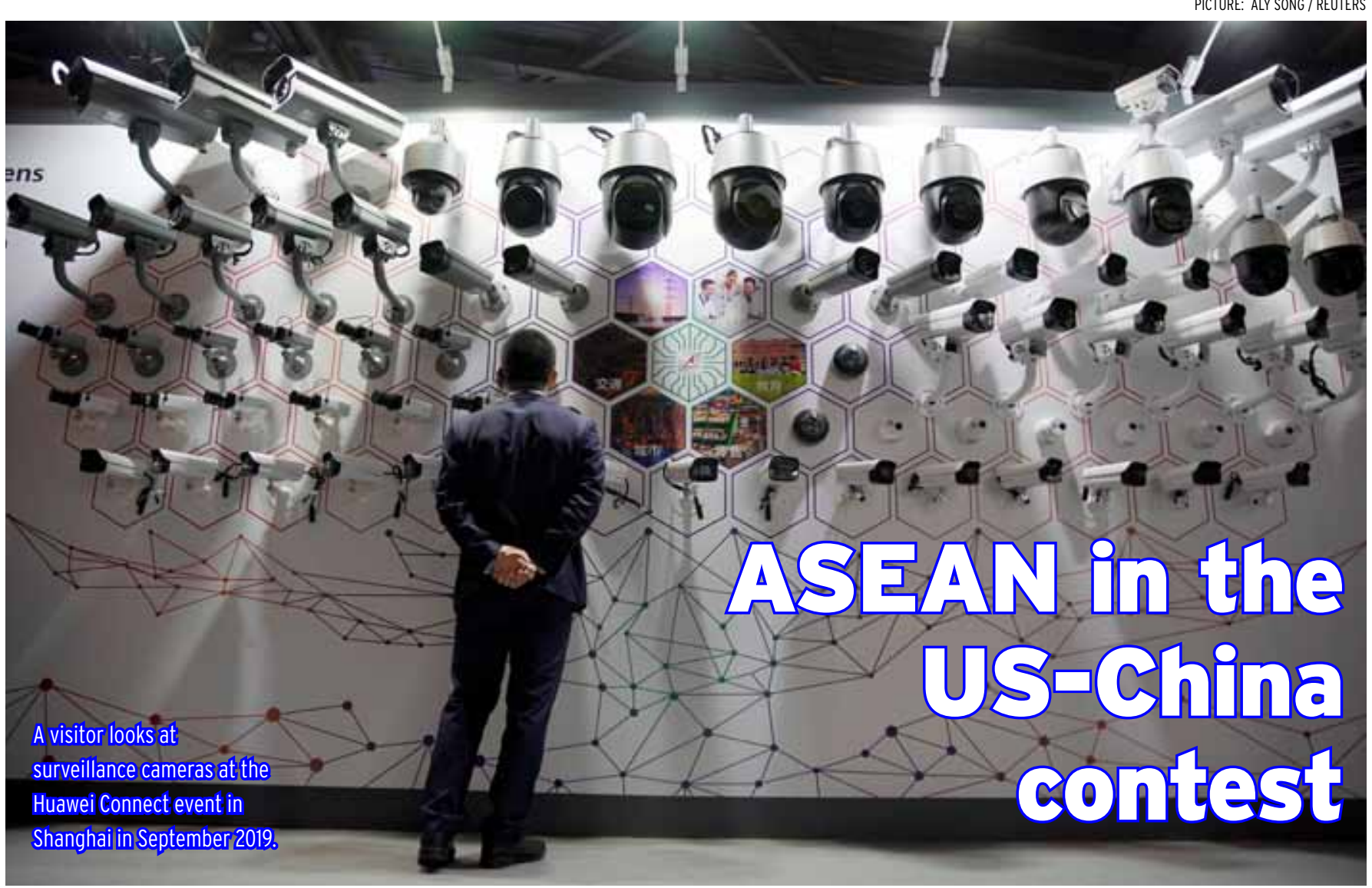

\section{SIMON TAY}

AND

JESSICA WAU

D ISING US-China tensions involve a broad range of issues, including strategy, security and values. It's pertinent to also look at the technology choices that ASEAN and others are facing in the context of this great power contest.

Given the advanced technology it offers and its relatively low cost, the Shenzhen-based company Huawei is a competitive option for any country looking to adopt 5G technology. Yet the US government has accused the company of violating US laws and being a 'persistent national security and foreign policy threat'. These accusations manifested in December 2018 with the arrest of Huawei's Chief
Financial Officer, Meng Wanzhou.

When the US Commerce

Department forbade US firms from selling equipment to Huawei-already the world's second-largest smartphone maker-the industry's entire supply chain was rattled. Now there is American pressure to convince other governments to ban Huawei from telecom infrastructure.

In economic terms of cost and benefit, the question for developing countries is how to obtain the newest and best quality $5 \mathrm{G}$ technology at the most competitive price. $5 \mathrm{G}$ not only enables faster mobile telephony but can also transform many sectors of the economy. However, some read the US decision on Huawei as a microcosm of broader political choices and alignments.

In China, some now buy Huawei products to display their patriotism.
In contrast, a clear decision to exclude Huawei has been made by a number of US allies - including Australia and New Zealand-which now face China's displeasure.

A few countries in ASEAN have opened their doors to Huawei. The Cambodian government inked a memorandum of understanding in April for Huawei to develop its 5G network. Major telecommunications companies in the Philippines also tapped on to Huawei's services, while Malaysian Prime Minister Mahathir Mohamad quipped that his country would use Huawei's technology 'as much as possible'.

But this should not necessarily be read as siding with China. There are sound reasons to allow Huawei in for cost and quality. The Indonesian government, for example, plans to decide on its $5 \mathrm{G}$ spectrum by means 
of auction in 2022. This presents the choice as purely a business decision.

In contrast, Vietnam has openly decided against Huawei. At one level this might seem like another example of strained politics between Hanoi and Beijing, but there are also national industrial policy reasons and business interests involved. Vietnam's largest mobile carrier, Viettel Group, fosters ambitions to develop its own $5 \mathrm{G}$ network equipment and is already active in Myanmar's telecommunications market.

In Singapore, the three main telecommunications companies are slated to work on $5 \mathrm{G}$ with multiple vendors, including Huawei. This seems to be a sign that the city-state will try not to be tied exclusively to one particular system. In August 2019, Singaporean Prime Minister Lee Hsien Loong noted that 'in such a bifurcated world, we still hope to be able to communicate with all our friends'

This points to a wider concern if systems are bifurcated. US-China tensions put pressure on broader choices in technology, infrastructure and standards. Various blacklists and differentiated tariffs can lead to multiple confusing systems of trade. Decoupling from economic interdependence would increase inefficiencies and add time, cost and uncertainty for cross-border business.

Concerns about decoupling go beyond business. At a strategic level, ASEAN must respond to the US 'IndoPacific' concept and China's Belt and Road Initiative (BRI).

The US Indo-Pacific push emphasises strategic and potentially military cooperation amid concerns that it is anti-China. Against this, ASEAN presented its own ASEAN Outlook on the Indo-Pacific, a consensus achieved during the 34th ASEAN Summit in June 2019. It offers a common script for each ASEAN state to remain relevant, neutral and united. In 2019 ASEAN engaged in a joint exercise with the US Navy: the inaugural ASEAN-US Maritime Exercise. In 2018 ASEAN held a similar maritime drill with China.

China's BRI has brought a welcome focus on infrastructure and connectivity, but there has been a chorus of criticism over the terms of some deals. One concern raised is that 'debt traps' are being created and that a host country might default and cede major assets like ports to Beijing. That has not prevented most ASEAN member states from trying to work with institutions like the Asian Infrastructure Investment Bank and China's state-owned enterprises. Infrastructure is essential for many countries and can multiply the value of diverse economic sectors.

Rather than judging these decisions chiefly in terms of siding with China or with the United States, it is more important to see these choices in terms of infrastructure and overall economic development.

ASEAN should not make a choice

\section{Decoupling}

from economic

interdependence would

increase inefficiencies

and add time, cost and

uncertainty for

cross-border business between one or the other but continue to engage both. In the short term, governments swaying between the United States and China should make choices on a case-by-case basis. This means taking a stance on an issue, not a country. Engaging both the United States and China is still the preferred policy for ASEAN.

Increasing US-China tensions are putting new pressure on that policy. The emerging reality is that each stance will likely influence the next. In technology, interoperability will have to be the long-term consideration. Parameters such as building up infrastructure, advancing technology networks and protecting citizens seem neutral but may not lead to an effective balancing act.

Some say it is necessary for ASEAN to speak with one voice on divisive issues, but the more realistic option would be for ASEAN member states to have more dialogue with each other as they frame decisions.

Sometimes the biggest changes do not occur in a single bold decision, but arise from a series of smaller ones. Each of those smaller decisions might be taken on its own merits but cumulatively add up to a strategic shift. It is too soon to conclude whether a country is siding with China or the United States. But it is immediately necessary for governments in the region to think through stances taken on different policy decisions, monitor how the choices add up, and work collectively to increase the space between the two competitors. EAFO

Associate Professor Simon Tay is the Chairman of the Singapore Institute of International Affairs.

Jessica Wau is Assistant Director (ASEAN) at the Singapore Institute of International Affairs. 


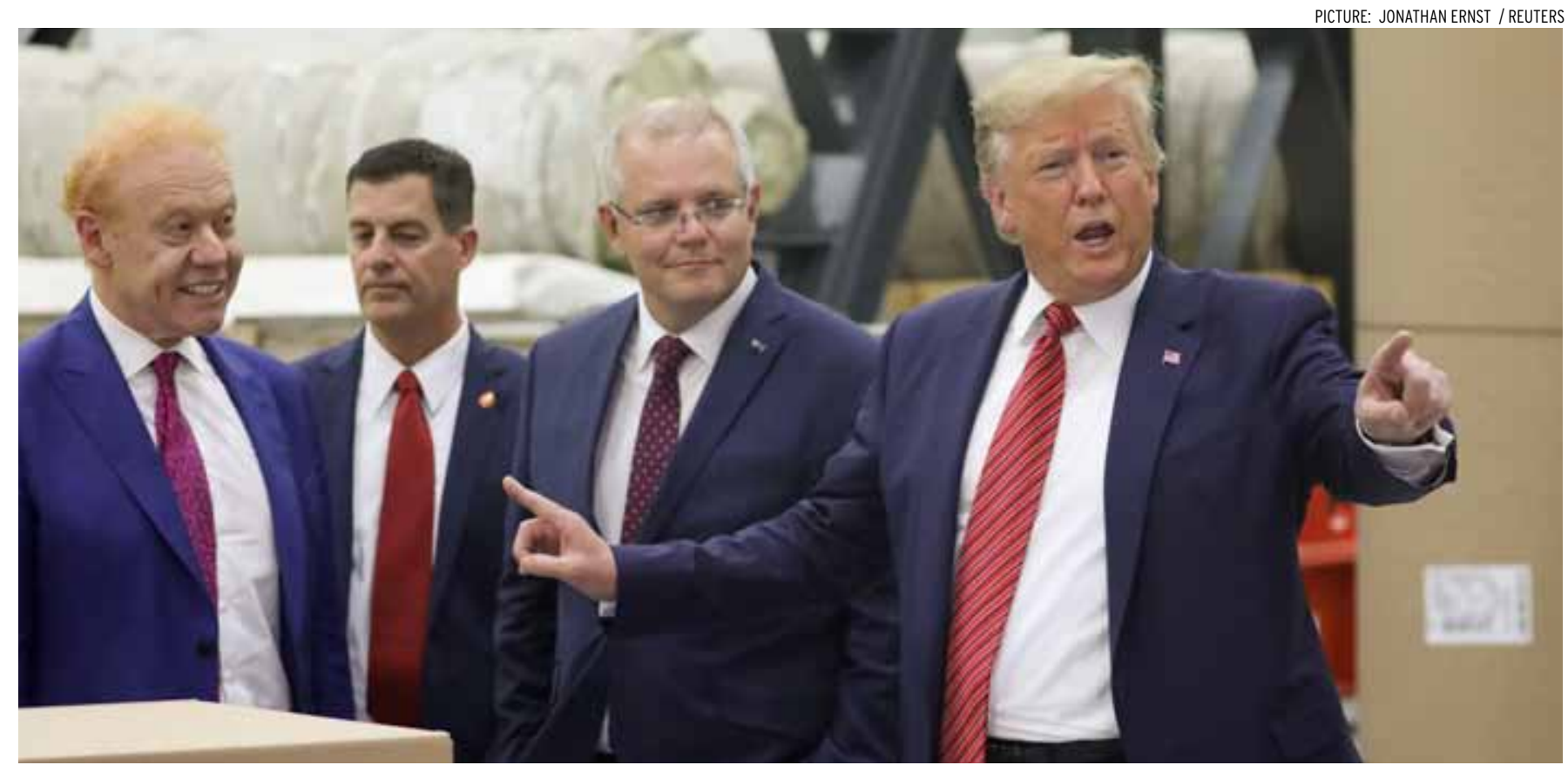

US President Donald Trump and Australian Prime Minister Scott Morrison, centre, during Morrison's visit to the United States in September 2019. Australia has kept its economic and security policymaking structures separate, but 'the changing strategic order makes this approach unsustainable'.

\section{Integrating Australia's security and economic policy cultures}

\section{BRENDAN SARGEANT}

\section{$\mathbf{0}$}

VER the past two years the debate in Australia about China has intensified and some of the optimism of a decade ago has dissipated. This is in part a result of Chinese actions, particularly concerning security, but also a result of shifts in US trade and economic policy towards China, along with a hardening of its security stance.

The idea that China would emerge as a major regional and perhaps global power is not new, and neither is the recognition that this would have profound implications for Australia. Despite having plenty of warning that China would become a major strategic and policy challenge, Australia has struggled to develop a framework that integrates different strands of policy to guide decision-making that relates to China in coming decades.

Why is this so?

Policy is built on ideas about the world and how it works. A feature of the Australian policy environment is the separation of policy into different domains. In particular, there is a strong separation between economic policy and security policy. This has been a feature of the Australian policy culture for decades.

One example is Australian policy towards the United States. Both Coalition and Labor governments have avoided linking the security and economic relationships, particularly in the area of trade and investment.
They have argued that the security relationship should be understood and managed separately from the trade relationship and that neither should be made hostage to the other. With China policy, governments of both persuasions have also tried to separate security policy from economic policy.

The changing strategic order makes this approach unsustainable, not least because China generally does not operate this way. Much of the debate on China policy is concerned with trying to strike the right balance between Australia's economic and security interests. Almost every issue concerning China brings these competing imperatives into play. This has been amplified by major shifts in US policy towards China and an 
increased willingness by the United

States to use economic levers to challenge China.

In consequence, the coming decades are likely to witness increasing economic nationalism, greater coercion using economic instruments and reduced confidence in institutions that have underpinned the rules-based international order. In this environment there is need to develop a strategic policy framework that integrates economics and security.

This is not only an intellectual challenge. It is also an institutional one. The structure of policymaking in Australia does not encourage a conceptual framework that integrates these imperatives. There is little focus on economic considerations in Defence and the Treasury's contribution to the security debate is negligible. Coordination from the centre is weak, even if the Department of Foreign Affairs and Trade has worked to bridge the divide. The 2017 Foreign Policy White Paper introduced some different ways of thinking about Australia's strategic environment and the policy instruments available, but this has not yet resulted in significant change in the policymaking culture.

$\mathbf{P}$ ERHAPS the challenge is deeper. Security and economic policy cultures embody profoundly different ways of thinking about the world. They look at the same environment and see different patterns and forces in play. They may not necessarily agree on what the strategic problems are or their significance and order of importance. They construct different versions of reality-the policy instruments available to them are very different.

The exercise of power through the use of economic instruments is quite different from the exercise of power using coercive instruments of the state such as armed forces. Decisions in either sphere will engage different interest groups. Time as a strategic reality and a resource is viewed differently. Both policy cultures have a tendency towards totalising frameworks, with the result that hubris can lead them to believe that they have the complete solution to almost all problems.

Can we afford not to do the hard work of integrating these different domains of professional endeavour into a larger conceptual framework?

The tools of both economic and security policy are a means to an end. We are in a world where states will use the instruments available to them to seek advantage and integrate different instruments of power to do so, although sometimes under the important constraint of agreed rules. China, for example, exercises coercive power through the use of economic levers, as well as more traditional means of coercion such as its claims to disputed territories and militarisation of the South China Sea. The United States is using tariff policy to achieve strategic ends in its relations with countries around the world, particularly China.

Australia has been able to sustain the separation of these domains because the rules-based order has allowed us to. Policy development has taken place in a strategic order that was stable, where either the rules governing that order were generally agreed upon or guaranteed by allied military power. The rules-based order allowed the establishment of institutions through which economic policy could be conducted. This has flowed back into the structure of Australia's policy environment and the way policymaking is conducted, although Australia was not an entirely passive player shaping this environment.

Australia has been an active and successful participant in the international system to help build and sustain the rules-based order, but it is entering a time where that order is being challenged. Australia must work to preserve what can be preserved and adapt where change is inevitable. It will require a much more selfconscious and active integration of the different policy instruments available. It requires the development of conceptual frameworks that integrate different strands of policy to maximise Australia's capacity to use instruments of national power to pursue national interests.

$\mathbf{T}$ HIS suggests the need for a very different policymaking culture and the development of appropriate institutional arrangements to support it. Changing policymaking cultures is difficult because cultures are embedded in institutions that respond to the world in ways that reflect the intellectual and professional frameworks and purposes that guide them.

Perhaps a first step might be to establish a new unit in the Department of the Prime Minister and Cabinet that would focus on the geopolitics of economic power in the Indo-Pacific. More than a coordinating role, it would need a mandate to integrate across government, drawing on the strength of existing institutions to lead the development of policies and a supporting institutional culture to meet Australia's needs in the new strategic order. ERFQ

Brendan Sargeant is an Honorary Professor at the Strategic and Defence Studies Centre, ANU. 


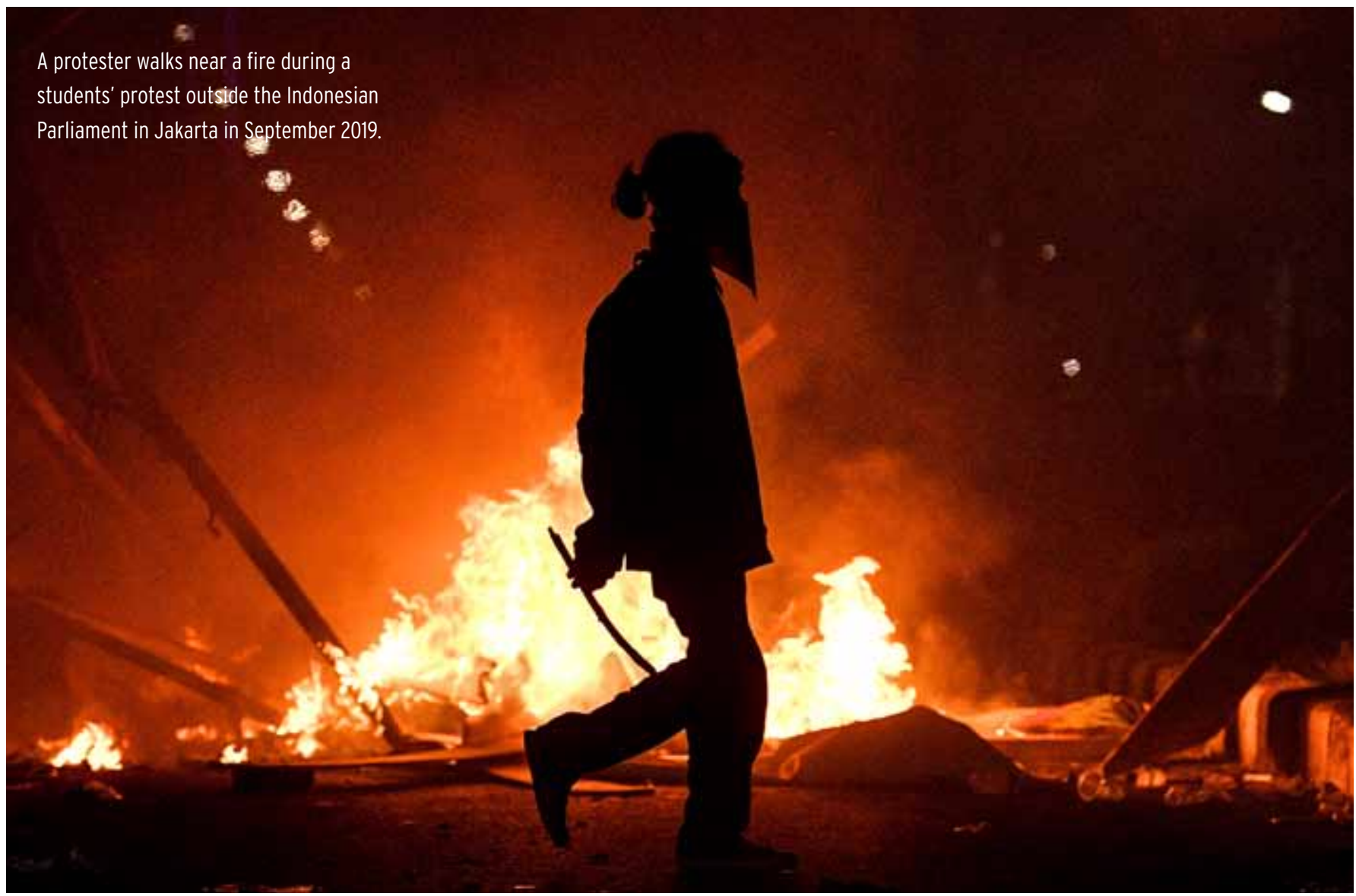

\section{Caught between political cartels and public interest}

\section{BURHANUDDIN MUHTADI}

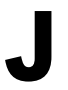

UST weeks before Joko

Widodo (Jokowi) was sworn

in for his second term as president, he was greeted with dwindling approval ratings due to massive student protests, forest fire crises in Kalimantan and Sumatra, and a violent communal conflict in Papua. Unlike the euphoria surrounding his first victory in 2014, Jokowi's second term starts in a much more sombre mood.

The public disillusionment, especially among students, stems from
Jokowi's handling of a controversial corruption bill, along with the agreement between his administration and the parliament (DPR) on revising the criminal code, besides other issues. These incidents have tarnished Jokowi's election victory and undermined his second-term agenda. There is now an imminent threat to democratic consolidation and the anti-corruption agenda as oligarchic political elites regain control of the levers of Indonesia's power. Jokowi's second term will also likely see further erosion of democratic values due to increasing global competition to boost economic growth as economic recession looms.

Still, Jokowi's success in the election is a victory for the stability and sustainability of development programs in Indonesia. From an economic standpoint, it is not difficult to predict the direction that Indonesia will take in the next five years. Based on his campaign promises, victory speeches and his State of the Nation address delivered in August 2019, the economy will remain his main priority. The focus is mainly on the fields of 
infrastructure development, human resource development, opening up further investment sectors and the perennial issue of bureaucratic reform.

Missing from Jokowi's speeches after his electoral victory was a focus on the agenda of human rights and eradicating corruption. Jokowi's attention to anti-corruption is limited to eradicating extortion, which can be interpreted within the context of his ambition to push ahead with massive deregulation. He also considers extortion to be a bureaucratic exaction that causes high costs for the economy and prevents foreign investment from entering the country.

At this point, there is almost no significant difference between the main agendas of Jokowi's first and second term. The game-changing factor is the constitutional term limit. Because Jokowi will not be able to run as a presidential candidate again, many predict that his performance will be less unconstrained by the electoral burden in his last term.

But observers may misinterpret Jokowi's statement about executing his government's agenda. In a speech he delivered at the 2019 National Development Planning Conference to formulate the government's 2020 economic agenda, Jokowi stated that 'in the next five years, I won't have any burden, I can't run again. So anything that will bring the most benefit for this country, I would do it without any hesitation... A narrow interpretation of the statement is that, when it comes to economic reform, he will govern without being hampered by concern about re-election.

Those who made overly optimistic assessments of what Jokowi's second term might look like-particularly on how he would govern unconstrained when it comes to political and human rights reform-misunderstand
Jokowi's character. Because his 'without burden' statement was made in the context of economic reform, one can only predict that Jokowi will be more courageous in carrying out unpopular economic policies to fulfil the commitment to the economic reforms that he promised.

For example, the Jokowi administration has submitted the government's plan to raise the Healthcare and Social Security Agency's (BPJS Kesehatan) contributions to 100 per cent due to the agency's severe financial deficit. Jokowi is strongly committed to repealing hundreds of regulations that suppress investment appetite. He is also prepared to revise Labour Law 13 of 2003, which has been considered too taxing for investors because of the excessive severance pay, burdensome minimum wage level, layoff provisions and prohibition on outsourcing permitted by the legislation.

Since his first term, Jokowi has shown greater interest in economic development than in democratic reform. There are a number of reasons why he might give the economy priority over human rights and anticorruption issues.

First, by emphasising economic issues, Jokowi encounters less

\section{Although Jokowi's}

\section{coalition looks secure}

\section{on paper, the supporting}

parties are not controlled directly by Jokowi, but by

the party oligarchs opposition and conflict with parliament and opposition parties. Improving infrastructure, creating jobs, developing a digital economy and accelerating economic growth are common goals that other political parties are more likely to support.

Recent surveys highlight the priority that Indonesians give to economic issues as compared to corruption and civil liberties. A 2018 study conducted a nation-wide survey of provincial politicians, who were asked to nominate the top three policy priorities of the government. Their responses were compared with a May 2017 public opinion survey that asked the same questions.

When the most common priorities for both citizens and legislators were compared, economic management and growth issues topped the list. Although both surveys indicated that economic growth was the highest priority, more than half of the politicians identified it as the top priority, whereas only a quarter of the public respondents did so. It is important to note that the survey included economics-related issues such as poverty and unemployment as separate categories to economic management and growth.

Unsurprisingly, few among the elites identified corruption as a highpriority issue. The number of public respondents who give corruption precedence is also unexpectedly low. Civil liberty issues such as overcoming discrimination and improving women's rights received less attention from both groups of respondents, particularly those from lower-middleclass backgrounds.

But this does not mean that economic issues are free from controversy. If Jokowi pushes ahead with economic reform and launches unpopular policies-such as increasing 


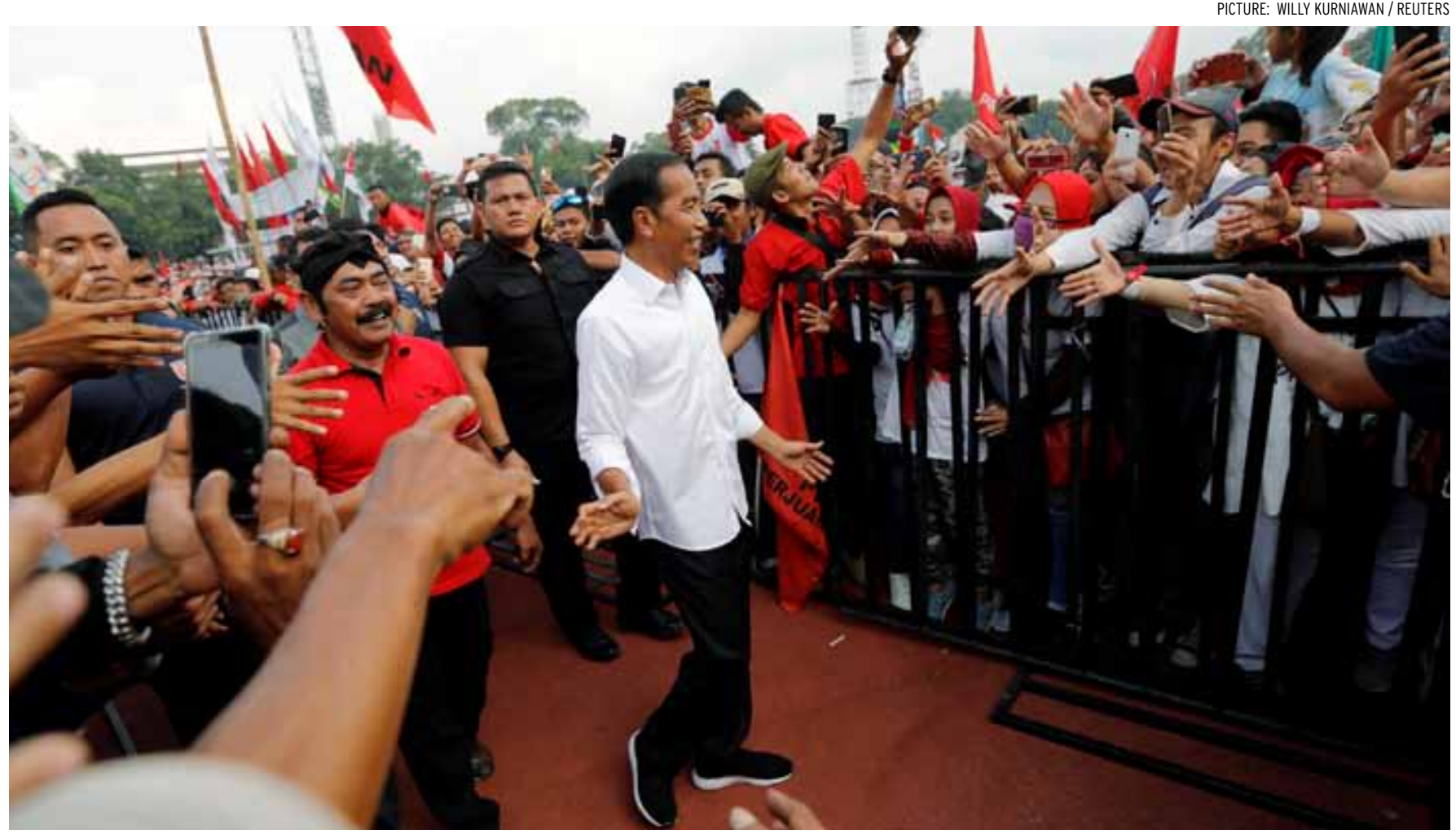

A 'simple and concrete' understanding of democracy: Joko Widodo greets supporters at a campaign rally in Solo, Indonesia, in April 2019.

fuel prices or revising the Manpower Act-he will have the benefit of being able to ignore the demonstrations and protests because he cannot seek re-election. But this political dynamic may not be the same for his supporting coalition. Although Jokowi cannot run again in 2024, his coalition parties still need to compete in the next election, creating different political incentives.

Jokowi could have added a new political party to his parliamentary coalition in anticipation of defections if he launched controversial policies. Although his coalition parties hold more than 60 per cent of parliamentary seats, if one or two parties defect, Jokowi's plan to execute his economic agenda would be in danger. And although his coalition looks secure on paper, the supporting parties are not controlled directly by Jokowi, but by the party oligarchs.

The second reason for Jokowi's focus on the economy is personal character, which helps to explain why he tends to ignore appeals for democratic reforms in favour of economic development and growth. Marcus Mietzner's portrayal of Jokowi as a technocratic populist explains why he gives priority to economic development issues. According to Mietzner, Jokowi's political outlook is a combination of non-ideological technocratic pragmatism and social empathy for the poor.

\section{EASTASIAFORUM}

Quarterly

OUR NEXT ISSUE ...

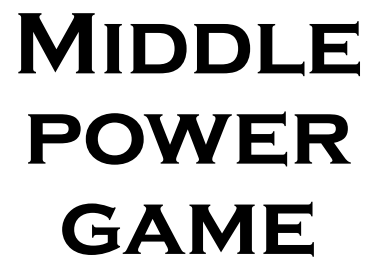

When it comes to democracy, Jokowi does not have a sophisticated vocabulary: he is not someone who likes philosophical or conceptual abstractions about democracy and freedom. His understanding of democracy is simple and concrete. During the 2014 presidential election television debate, Jokowi interpreted democracy simply as listening to the people and taking concrete action'. For Jokowi, democracy is meaningful as long as people can enjoy development and social welfare.

Jokowi tends to view noneconomic issues as secondary, or merely as instruments to advance economic development. If his economic ambitions collide with the anti-corruption agenda, he tends to prioritise the former. Jusuf Kalla, his former vice-president, also commented that democracy is only a 'tool' to achieve the goals of people's welfare. This view is problematic 
because people's welfare can be achieved without democracy, as in the cases of China and Vietnam, where political stability and economic growth are pursued at the cost of individual freedoms.

The implications of this narrow understanding of the Indonesian political system could be dire, as democracy and civil rights may be forfeited in the name of political stability and economic development.

This also means that democracy and anti-corruption agendas must be framed within an economic context. The most concrete example is Jokowi's directives in 2015 to the Cabinet Secretariat to circulate a letter to lawenforcement officials instructing them that the policies of regional heads would not be held hostage to threats of criminal conviction and corruption accusations. Regional heads had been reluctant to disburse local-government funds for fear of being pursued by the Corruption Eradication Commission (KPK), even though the economic slowdown needs to be overcome by an increase in government spending.

Jokowi's reluctance to pursue democratic reform also stems in part from his inability to run for election again in 2024. In his first term Jokowi still had electoral incentives to demonstrate his concern for the trusted law-enforcement institution, the KPK. The issue of human rights might still receive some attention because there were segments of voters who cared about this issue in the 2019 election. But the electoral incentive disappeared upon his second inauguration. With the democratic reform agenda taking a backseat, there is potential for Jokowi's second term to be more conservative when it comes to maintaining political stability and tolerating dissent.

This is exactly what happened in the weeks leading up to Jokowi's second inauguration. After his election victory, Jokowi and his immediate circle moved to prepare a blueprint for the economic agenda of his second term. There is little monitoring of the discussion of the Draft Law Bills, both proposed by the government and the parliament. Also, the DPR's custom is to speed up the completion of legislation at the end of a term of office, regardless of how strong the controversy in civil society is.

The entrenched oligarchic forces that have defined Indonesian politics since the New Order era have certainly exploited Jokowi's indifference towards democratic reform and anticorruption efforts. These oligarchic groups not only have total control over the political parties but are also part of an elite economic class which controls the material resources that steer the course of Indonesian politics. Inside and outside the country's corridors of power they joined forces in passing the KPK Law Revision that undermined the anti-corruption agenda. They also tried to pass various revisions to the law in favour of their narrow interests at the expense of the public interest.

This was the backdrop to demonstrations in Jakarta and various Indonesian cities several weeks before Jokowi's inauguration - the biggest protests since the fall of Suharto. This

\section{The huge student}

movements have

surprised Jokowi and the political elites blindsided Jokowi, who only then realised the degree of controversy surrounding the articles in the bills soon to be enacted. Among them was the article that appears in the revision of the Criminal Code on insulting the president that threatens freedom of opinion, and the treason article that suppresses civil society's freedom of expression.

The draft Land Law is also controversial, with the proposed conviction of displaced victims of eviction on the grounds that those who resist eviction in the public interest are seen to be interfering with development. This article facilitates infrastructure development that has been hampered by land acquisition constraints. The Penal Act is no less controversial, making remission for those convicted of corruption easier.

The revision of the KPK law, containing articles on weakening the KPK and eradicating corruption, was swiftly passed in the DPR. However, the DPR and the government postponed ratification of the Bill on the Elimination of Sexual Violence that protects women. Interestingly, all parties tended to agree in passing the aforementioned problematic laws. There appears to be no ideological difference between coalition and opposition parties in this case.

This phenomenon highlighted what has been termed by political scientists Dan Slater and Dodi Ambardi as political cartelism in Indonesian politics. Political competition and ideological differences cease the moment election season is over, and party elites instead turn to collusion.

This re-awakened the student movement that had been dormant since the 1997-1998 reform movement. Students and civil society movements felt a serious threat to the reform agenda that they had fought 
for, particularly freedom of expression and measures against corruption.

The huge student movements have surprised Jokowi and the political elites. The students' narrative is actually separate from common concerns, rejecting the weakening of the KPK and threats to civil libertieslower priority issues from the public's perspective. But the students managed to attract general public attention by making the DPR their main target. In the eyes of the public, the DPR is a poor democratic institution-making it easy for students to attract public sympathy by attacking it, even though the issues that they protest may seem abstract.

The latest national survey, conducted in October 2019 by Lembaga Survei Indonesia found that 59.7 per cent of voters knew or followed news about the student protests. Among respondents, the majority supported the student agenda, rejecting the revision of the KPK law that was widely viewed as an effort by political elites to weaken the agency. They also supported the students' attitudes towards the several problematic bills previously mentioned.

Among the respondents who knew about the revision of the KPK law, 70.9 per cent believed it to be weakening the KPK, and only 18 per cent agreed with the elites' argument that the revision would strengthen the KPK. A huge 76.3 per cent of respondents agreed to ask Jokowi to issue a Perppu, a Presidential Decree as Substitute to the Law, to cancel the new KPK law.

It appears reasonable from a political perspective for Jokowi to postpone the problematic laws, but he has yet to issue a Perppu. There was strong resistance to the Perppu proposal from the political elite. Both the government coalition and the

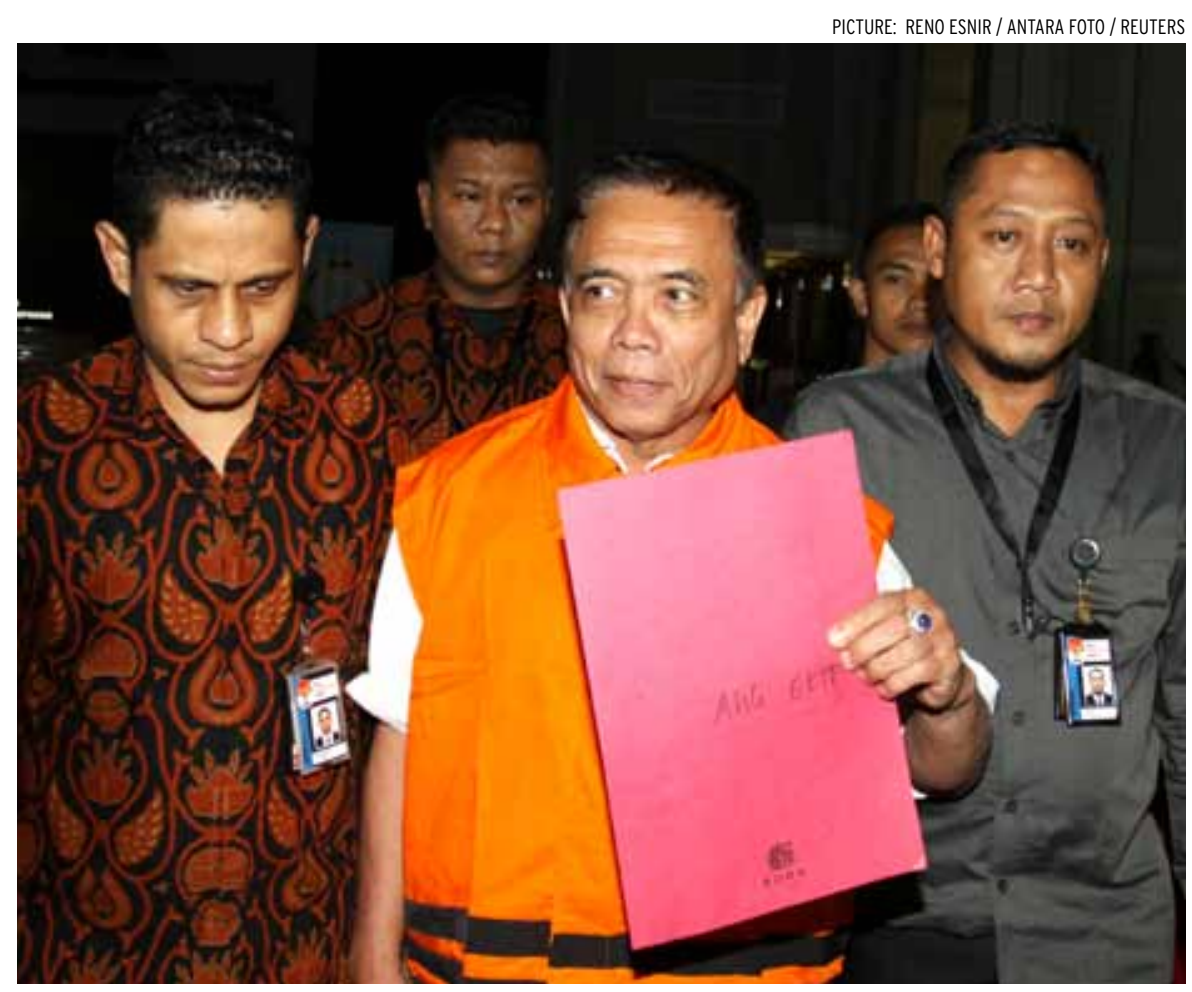

Irwandi Yusuf, governor of Aceh province, with Corruption Eradication Commission (KPK) officers after his arrest in June 2018. Many fear that proposed changes will weaken the agency.

opposition party have warned Jokowi that if he does issue a Perppu, it could lead to an impeachment process by citing disrespect towards the parliament as the highest law-making institution.

Jokowi's second term is likely to be marked by an increasingly intimate relationship between oligarchic powers and political cartels on issues that threaten reform and eradicate corruption. They are adept at utilising Jokowi's lack of interest in democracy and combating corruption.

The consolidation of oligarchic forces has become increasingly apparent with lobbying for the People's Consultative Assembly (MPR) to amend the 1945 Constitution by reviving the Suharto-era Guidelines of State Policy (GBHN). If the amendment were to be passed, it might open a Pandora's box that would include amending the presidential election system which has been a trademark of democratic reform. The MPR is now led by Bambang Soesatyo, who openly declared his support for presidential elections via the MPR as done under Suharto.

The consolidation of the oligarchs and political cartels that have defined Indonesian politics for decades presents a problem for Jokowi. The economic reform agenda he wants to carry out will not run smoothly without their political support. But if Jokowi tries to ignore the demands of the people, then widespread public resistance will disrupt political stability and his economic agenda too. The question will be whether Jokowi listens to the calls of the people or falls into the oligarchic trap. EAFQ

\section{Burhanuddin Muhtadi is a Political Science Lecturer at Syarif Hidayatullah State Islamic University, Jakarta, and an executive director of Indikator Politik Indonesia.}




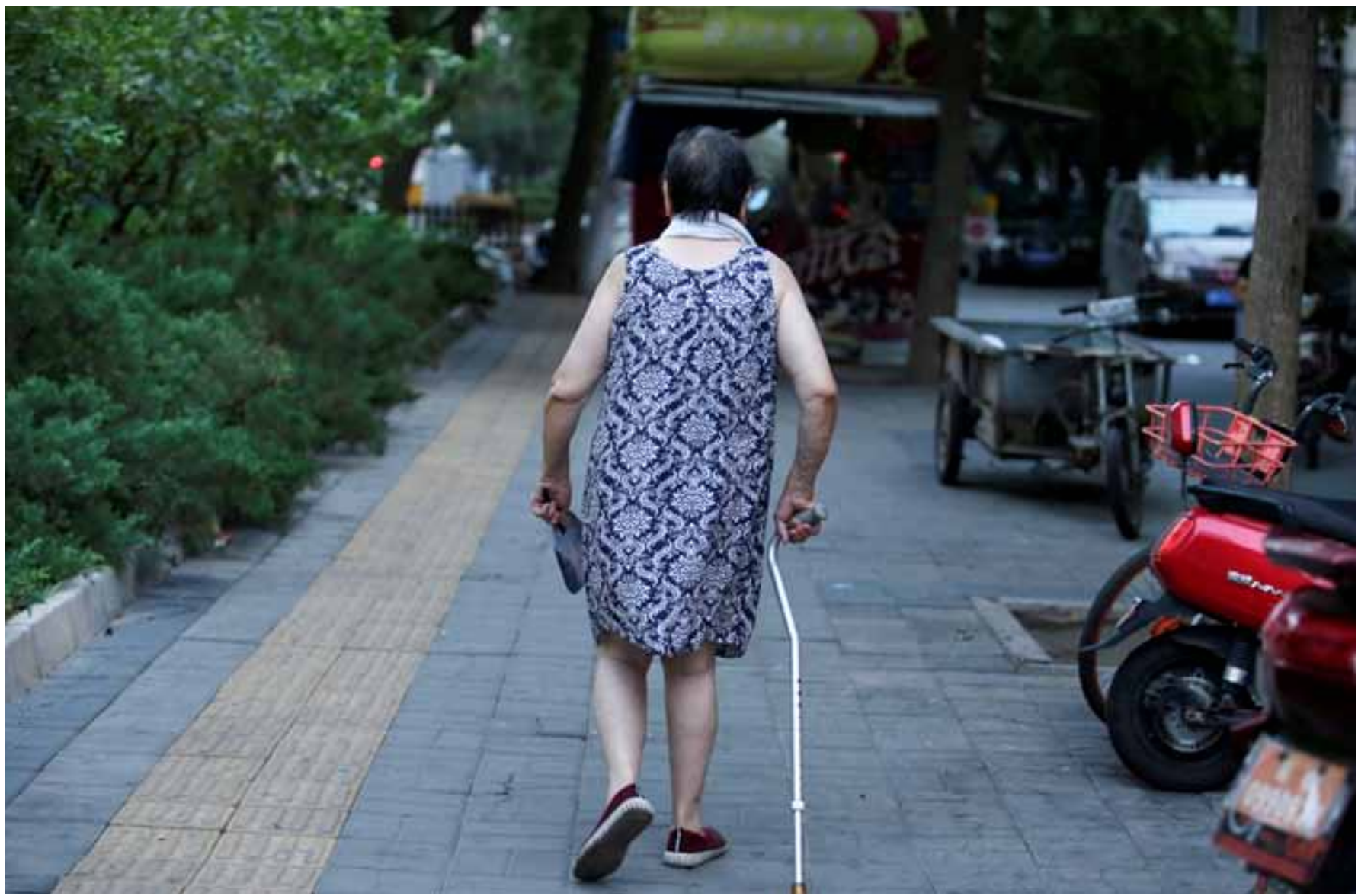

\section{Meeting the challenge of China's population change}

XIAOYAN LEI

AND

CHEN BAI

D EMOGRAPHIC transition is an important factor in explaining China's rapid social and economic development since reform and opening up began in 1978. As early as the mid-1960s, China's population began to move gradually into a phase of 'low fertility, low mortality and low growth' as the country's fertility peaked. In the 1970s and 1980s, the rapid increase in the working-age population and continuous decline of the country's total dependency ratio (the ratio of the workforce to total population) finally gave rise to a 'productive' demographic structure, characterised by the working-age population's being larger than the population of the young and the elderly.

This population structure released a huge 'demographic dividend' that stimulated China's rapid economic growth not only by guaranteeing a more sufficient supply of labour, but also by promoting the substantial accumulation of domestic savings.
However, the continuous decline of the fertility rate and prolonged life expectancy have accelerated the ageing of the population, resulting in the transition of the population structure from 'productive' to 'indebted'where the population of the young and elderly is now larger than the working-age population. The shrinking demographic dividend and ageing of the population have now become a major challenge for China's economic development.

According to the most recent population projections released by 
the Population Division of the United Nations, World Bank Group and China's Population and Development Research Center, the ageing of China's population will have four main characteristics in the coming years.

The elderly population will enter a period of sustained high growth, especially after 2030, when the average annual growth of the population aged 65 or above will exceed 11.2 million. At the same time, the process of ageing is intensifying. In 2050, the number of people over age 65 is expected to exceed 400 million, close to one-third of the total population. At that time, about 10 per cent of all households will have at least one member over age 65 . The proportion of the elderly in China's population will not only be higher than the average for OECD countries, but also twice that of less developed countries.

The growth of the elderly population will gradually transition from the young-old (60-80) to the oldest-old (over 80). While the proportion of the younger elderly is decreasing year by year, the growth rate of the oldest-old can be expected to increase sharply. Around 2050, the number of the oldest-old will reach 144 million-about the total population of Russia-and will exceed the total number of oldest-old in Europe and North America.

The total dependency ratio will continue to increase and will reach about 73 in 2050 . That is, every 100 people in the working-age population will need to support 73 people, including 22 children and 51 individuals aged 65 above. At that time China's total dependency ratio will be 32 points higher than it was in 2018 (at 41), nearly the same as the average level of Europe's total dependency ratio in 2050 and much higher than the average developing country's total dependency ratio of 57 .

This rapid ascent will be mainly due to the sharp increase in the old-age dependency ratio.

By around 2030, the old-age dependency ratio will be greater than the child dependency ratio. This means the obligation of care for the elderly is increasingly becoming the main burden for the workingage population. By 2050, the old-age dependency ratio in China will have risen to 49.9, which will be about 6 points higher than the average level of the OECD countries (at 43.9).

The decline in household size in China is occurring primarily because of the country's demographic transition, especially in urban areas. According to demographic research, the country's average household size started to decrease in 1982, when strict family planning policies were launched. Since then, the average family size has continued to drop, from 4.4 in 1982 to 2.89 in 2015. Over the next 30 years, China's average family size will decrease to 2.51 , and the downtrend will be most dramatic in rural areas.

Correspondingly, there will be unprecedented growth in the number of elderly individuals living alone-so called 'empty-nest elderly'. The number of empty-nest elderly suffering from insufficient care and companionship from family members is projected to

\section{Over the next 30 years}

the share of the

working-age population

will decrease rapidly increase from 17.5 million in 2010 to 53.1 million in 2050. Particularly in urban areas, the number of elderly people living alone will increase sharply, from 7.8 million in 2010 to 39.7 million in 2050 , nearly triple that in rural areas.

Consequently, China is facing a new demographic transition. And due to decreasing fertility and the forthcoming wave of ageing baby boomers, the speed and depth of the population ageing process will inevitably increase. The change in the population pyramid, which is characterized by 'contracting at the bottom and widening at the top', further reflects not only the compression and ageing of the working-age population, but also the increasingly heavy burden of care for the elderly.

Population change will undoubtedly pose a series of challenges to the sustainability of China's social and economic development.

In general, there are two mechanisms through which population ageing is likely to affect economic growth in China, as with many other ageing countries. The first is the decreasing supply of labour. With the overall fertility rate continuing to be sluggish, the everexpanding population of people over age 65 will continue to compress the growth of the working-age population. Over the next 30 years the share of the working-age population will decrease rapidly due to the ageing of the population. By 2050, the number of working-age people will be reduced by about 200 million.

Population ageing also decreases a country's stock of human capital, which affects economic growth. While delaying the retirement age somewhat alleviates the problem of decreasing labour supply, older workers are 
not perfect substitutes for younger workers, so there may be a decline in productivity per worker.

The second mechanism is the effect of ageing on savings and investment growth. On the one hand, an increase in the elderly population tends to reduce the savings rate for retirees as savings become the source of their spending. As a result, it will be difficult for China to maintain a relatively high level of domestic savings, as it has been able to do over the past 30 years. On the other hand, a larger ageing population as a proportion of the total population will lead to an increase in government spending, especially on health care, pension security and other welfare benefits for elderly people. Accordingly, the resources available for productive investment will decline, and that will ultimately affect economic growth. Private consumption may also be weaker. That might drive down aggregate demand and, therefore, the incentive for businesses to invest.

Although the challenges of China's ageing population might be similar to those in developed countries, there are some differences.

The rapid ageing process has placed a burden on China that is comparable to or even heavier than that experienced by the developed countries, but as the largest developing country China must respond to this tough ageing challenge-having the largest number of elderly people in the world-with social security and health care systems that are not yet as well-established as those in Western countries.

Meeting the 'ageing before getting rich' problem will mainly be addressed in two ways: through pension reform and changes in traditional family care.

The pension system is the cornerstone of old-age support.
It is also necessary

to strengthen health

investment and promote

healthy ageing

As early as the 1980 s, the Chinese government began to attempt to reform the pension system by transitioning from a pay-as-yougo approach to a partially funded approach combining social pooling accounts and individual accounts. However, the reform has not been fully carried out so far. What is worse, as the largest wave of baby boomers step into old age, the number of pension recipients is expected to rise sharply while the contributing population will gradually decrease, resulting in a widening of the potential pension funding gap. The cost of the transition and the implicit debt have put the current imperfect pension system under funding pressure. If the pension insurance system cannot be further developed, funding pressures with the arrival of the peak period of growth of the elderly population will result in a heavy financial burden.

Traditional informal elderly care by family members has always been China's leading mode of care for the elderly, but the demographic transition brought about by rapid population ageing is eroding the population base of family care. For example, nowadays the average Chinese elderly person has multiple children. But when the average baby boomer who was born in the 1950s or 1960s reaches old age, they will have fewer than two children. As these people age over the next
30 years, the number of empty-nest elderly will expand. In this case, traditional family care is bound to face more severe challenges. Because formal care services such as institutional and community care services are still in their infancy, the increase in the burden of family care will have an adverse impact on the supply of labour and accumulation of human capital in the long run.

Faced with the severe challenges brought by population ageing, the Chinese government will not only have to promote the reform and innovation of its social security system, but also address urgent issues such as building a long-term care system and providing medical security for ageing workers. It is also necessary to make full use of modern technology to improve the utilisation and efficiency of human resources and to cope with the challenge of a decreasing future labour supply.

The practical results of the 'universal two-child' policy, which was launched in 2014, are much lower than had been expected. Implementing a more active population policy would help to promote balanced population development and increase the supply of labour in the long run. Policies that encourage families to have more offspring are expected to increase the number of children in the average family to two or three. Achieving this would not only require a complete relaxation of fertility control but also the establishment of a series of services and guarantee systems, such as family support plans, infant and maternity care subsidies and female employment protection.

China's demographic dividend is not as dominant as it was in the past, but the comparative advantage of the country's population structure still lingers and there is still much room for 
human capital improvement.

The implementation of a lifelong learning policy strategy can comprehensively improve the quality of the labour force by expanding the coverage of education and training programs for all people during their lifespan. Accelerating the growth of the digital economy and technological innovation will provide greater support to cultivate and train hightech talent, in particular. It will also help to create more and new forms of working opportunities which are also suitable for elderly people, and enhance the efficiency of labour.

It is also necessary to strengthen health investment and promote healthy ageing. For older workers, it is especially important to focus on strengthening occupational health services, disease prevention and improving work environment and safety. At the same time, the government needs to improve the medical care system, improve the convenience and accessibility of medical services for the elderly, and improve the structure of the social pension service system. Faced with the prospects of an increase in empty-nest elderly and fewer children, improving the quality and supply of institutions and communities can help to reduce the burden of family care.

The most significant issue for pension reform is to establish a multi-level pension system that is compatible with an ageing society. Much more attention will also need to be paid to encouraging participation and empowering the current pension system. This would not only help to alleviate the pressure of potential pension financing problems but also make better use of newfound savings motives that arise from the extension of life expectancy. This can help to maintain a high level of national savings for the future of the economy.

A proper system should

be established to improve the management and investment of pension funds, which could contribute to preserving and increasing the value of these funds. Faced with the ageing of the working-age population, a reasonable extension of the retirement age and the exploration of more flexible retirement mechanisms would also help to alleviate social security system funding pressures and expand labour supply. EAFQ

Xiaoyan Lei is Professor of Economics at the China Center for Economic Research (CCER), National School of Development, Peking University.

Chen Bai is Assistant Professor at the School of Labor and Human Resources, Renmin University of China.

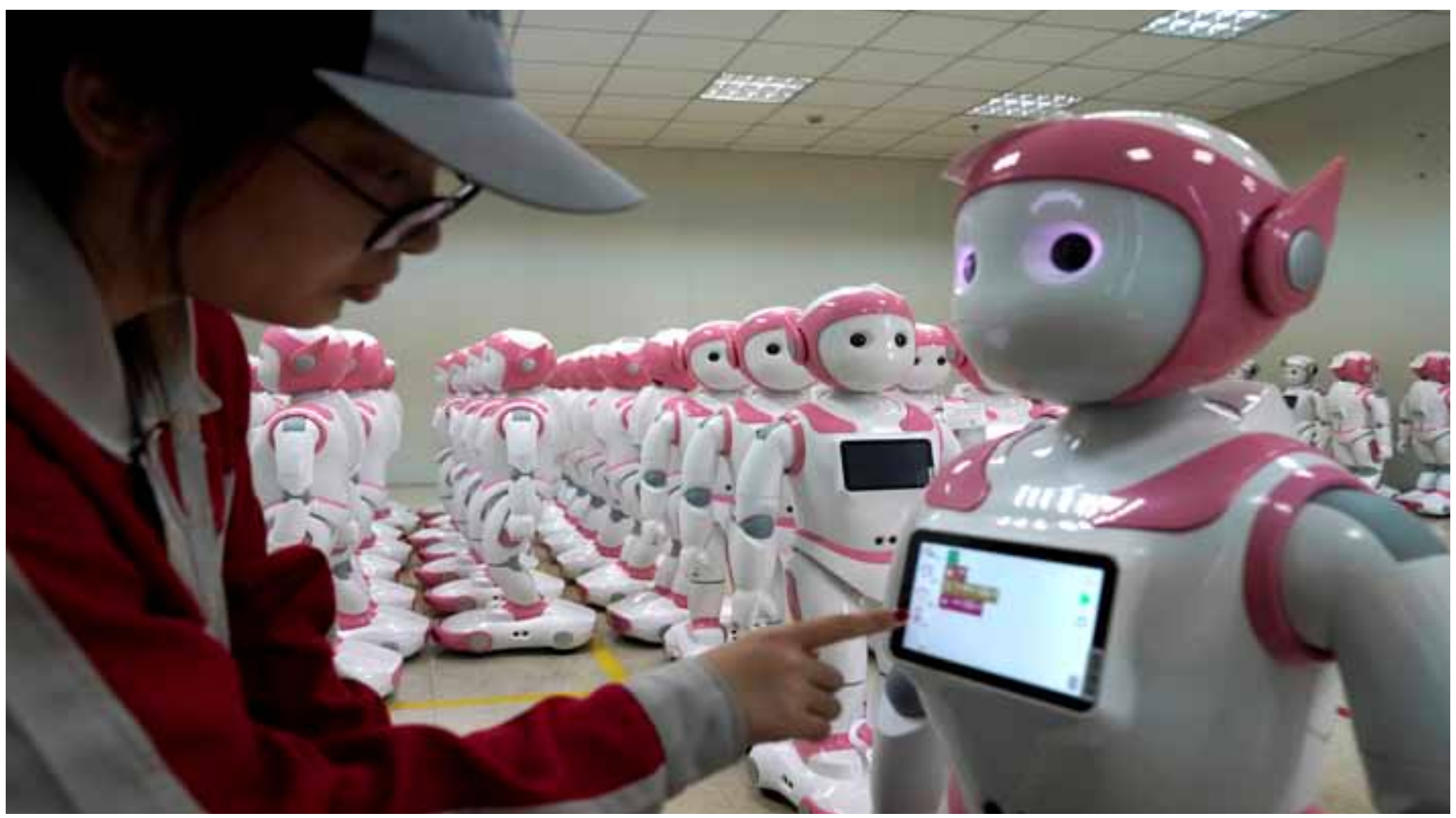

A friendly companion: a worker at the AvatarMind plant in Suzhou puts finishing touches to an iPal social robot. The robots, slightly more than a metre tall, are designed to offer education, care and companionship to children and the elderly.

PICTURE: ALY SONG / REUTERS 
PICTURE: ADNAN ABIDI / REUTERS

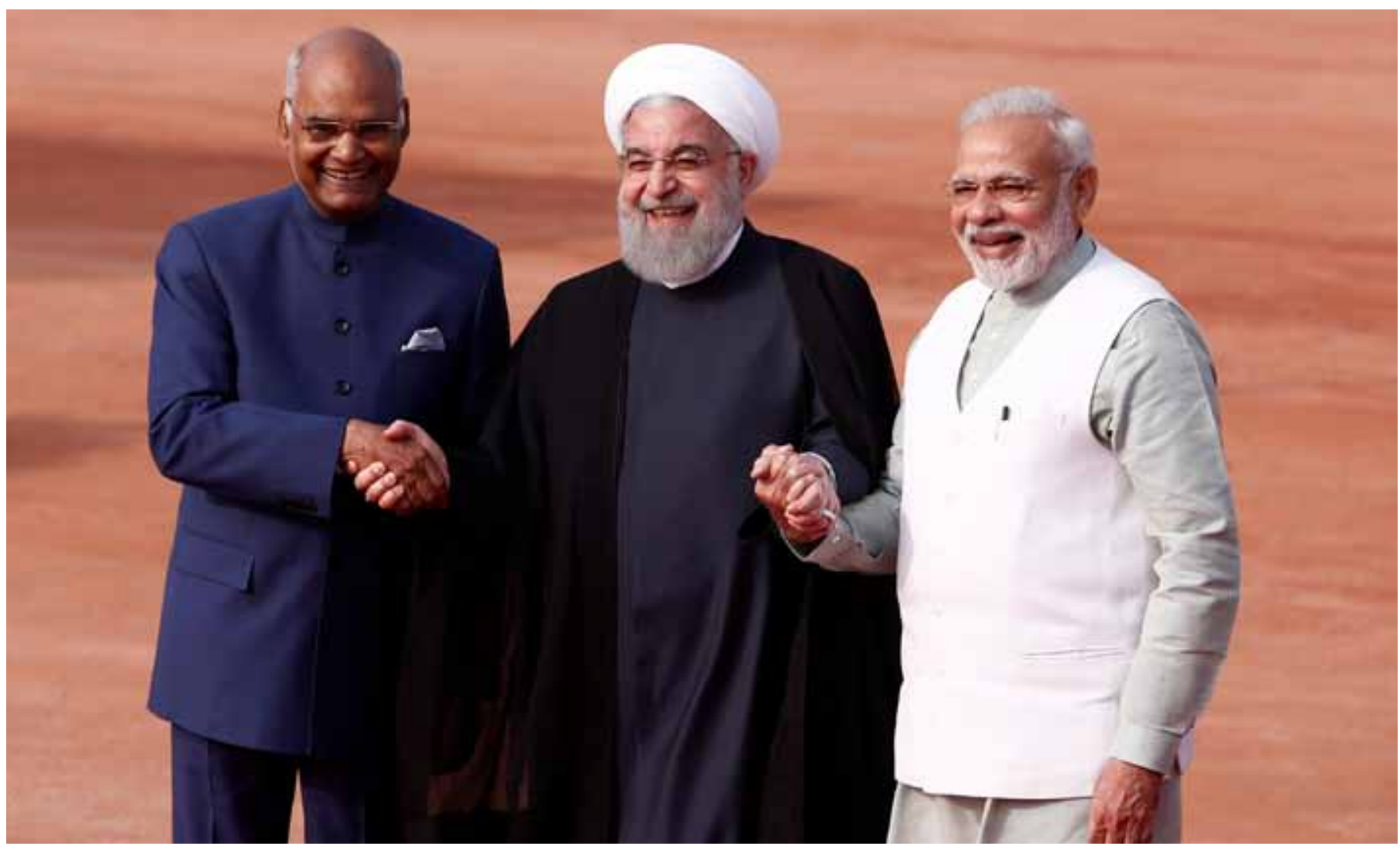

Iranian President Hassan Rouhani with Indian President Ramnath Kovind, left, and Prime Minister Narendra Modi at a reception in New Delhi in February 2018.

\section{Iran turns to China and India in the face of US sanctions}

\section{MOHAMMAD SOLTANINEJAD}

N THE face of the United States'
withdrawal from the Iran nuclear
deal and its adoption of a 'maximum
pressure' policy against Iran, Tehran
has been compelled to turn to Asia-
in particular to China and India-to
circumvent the American sanctions.
In response, the United States is trying
to deny Iran's access to Chinese and
Indian resources to pressure Iran into
returning to the negotiation table.
Both China and India have long
had the potential to become strategic
partners to Iran, but efforts to establish

such partnerships were undermined by the United States. Yet the idea of strategic partnerships remains alive due to the geopolitical and geoeconomic factors that link China and India to the Persian Gulf, Afghanistan and Central Asia. A review of the dynamics of Tehran's relations with Beijing and New Delhi suggests various avenues of cooperation in the face of US policies against Iran.

In defiance of US demands to tighten the noose on Iran, Beijing is showing a hesitant willingness to continue working with Tehran. China continued to import Iranian oil despite
US sanctions and news leaked about negotiations over China's prospective investment of US $\$ 280$ billion in Iran's oil and gas industry. Replacing the dollar with the renminbi as a transactions currency has facilitated China-Iran trade and financial cooperation.

There are other important signs of China's readiness to pay the necessary price to maintain long-term strategic and business relations with Iran. The chief financial officer of Chinese telecom giant Huawei, Meng Wanzhou, was arrested in Canada in December 2018 on suspicion of 
violating US sanctions against Iran. Two months earlier, a Chinese national was detained in Washington on similar suspicions. These facts suggest that China is prepared to defy the United States' maximum pressure policy.

China needs Iran as much as Iran needs China. To cope with the US policy of containment, China relies on Iran to diversify its energy supply. The majority of China's oil imports currently pass through the Strait of Malacca, which is controlled by US allies in Southeast Asia. China can overcome this strategic predicament if Iran's gas flow is connected to the Gwadar port pipelines in Pakistan. This explains China's readiness to invest in the development of the southeastern Iranian port of Chabahar from which Beijing can also access Afghanistan, Central Asia and Russia.

In addition to China's assistance, Iran also wants India's support to counter US pressures. India preceded China in establishing constructive strategic ties with Iran. During the 2000s, Iran-India relations experienced unprecedented progress that led to India pledging to invest a considerable amount of money in Iran and planning for military cooperation between Tehran and New Delhi. Back then, Iran was trying to counterbalance the United States after the latter included Iran, together with Iraq and North Korea, in the 'axis of evil'. The US invasion of Iraq after Afghanistan alarmed Iran further and pushed it to strengthen ties with second-tier powers, including India. For its part, India found developing ties with Iran very beneficial. The International North-South Transport corridor could connect India to Central Asia and Russia and Iran, and could increase India's influence in the Arabian Sea. Strategic and economic reasons to establish a partnership between Iran and India still persist. India has great strategic interests in developing ties with Iran and is the greatest investor in the development of Chabahar.

In theory, India-Iran cooperation should be easier than that of China-Iran, because in contrast to its strong rejection of the Iran-China partnership, Washington is more tolerant of India's deepening relations with Iran as its interests in the Indian Ocean, the Arabian Sea and the Persian Gulf are best served if India and Iran work together. As part of its grand strategy of offshore balancing, the United States has invested in India's leading role in the Indian Ocean and the Indian subcontinentparticularly in Afghanistan.

With US troops ultimately leaving Afghanistan, India can serve as the party on ground that protects US interests by fighting terrorism and strengthening the central government in Kabul. This would be difficult to achieve unless India has easy access to Afghanistan. Given the rivalry between India and Pakistan, Iran remains the best route that connects

\section{From an Iranian}

perspective, China's rise

is quite different from

India's advance towards

joining the club of great

powers
India to Afghanistan. This explains the United States' relative tolerance of India's ties with Iran in the Arabian

Sea and its decision to waive sanctions on India's investment in Chabahar.

In practice India has shown reluctance to work with Iran after the United States' withdrawal from the nuclear deal. India stopped purchasing Iranian oil in May 2019 and reduced the budget allocated to the development of Chabahar to around one-third of its original size. Indian involvement in the development of this port has nearly come to a halt. Financial arrangements to facilitate trade between Iran and India are in flux, meaning that importing Indian medicine, food and other commodities will become more difficult for Iran.

The temporary exemption of Chabahar from US sanctions did little to help India develop this significant port. The major problem was that the suppliers of the equipment that Chabahar needs were not willing to make deliveries because they feared adverse impacts on their business with the United States.

These realities have convinced Tehran that India cannot be the partner it needs to counter US sanctions. India is a rising power on the global stage and owes that, in part, to its growingly close relationship with the United States. This means that no matter how valuable Iran is for India, New Delhi would not endanger its relations with Washington for the sake of preserving its friendship with Tehran.

Although Iranians are also well aware that Beijing would not sacrifice its relations with the United States for its partnership with Iran, they still believe that China will support Iran more strongly than India. China's continuation of its trade with Iran and the purchase of the Iranian oil is proof 
of that. From an Iranian perspective, China's rise is quite different from India's advance towards joining the club of great powers. India's economic and military development contributes more to preserving the pro-US international status quo, while China's rise is seen to come at the cost of the United States' global position and points towards a more balanced global power distribution. Iran also sees that China's reaction to US sanctions on Iran is different from India's.

Despite the difference in China and India's readiness to work with Iran, the United States remains the force that ultimately determines the direction and depth of both countries' cooperation with Iran. China withstood US pressures to stop trading with Iran but it cannot shield Iran from all of the United States' adverse policies.

China has its own problems with the United States with the ongoing trade war, and it is unlikely that China will want to risk worsening them by supporting Iran. Decision-makers in Tehran are aware of this and are wary of putting all their eggs in the China basket.

Nor does Iranian public opinion support a close partnership with China. If Iran-China ties grow substantially and quickly, the Iranian government is likely to find it difficult to convince its people that the independence from the West that they gained so expensively will not be lost to dependence on China. EAFQ

\section{Mohammad Soltaninejad is an} Assistant Professor of Middle East Studies at the University of Tehran.

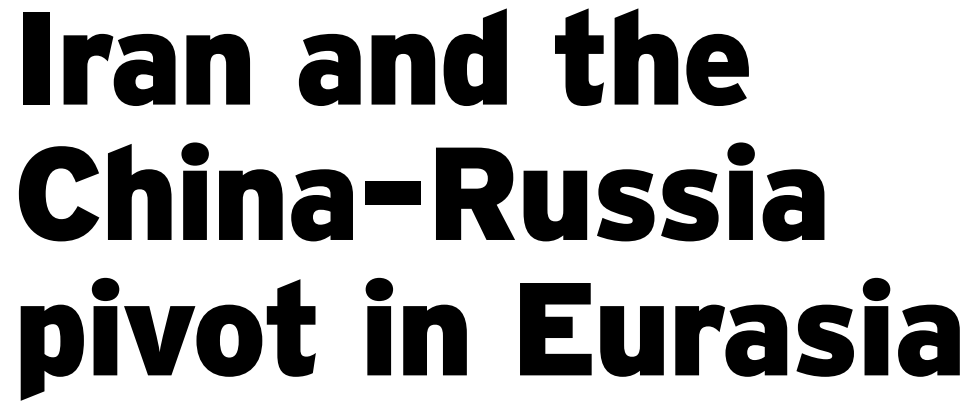

MICHA'EL TANCHUM

RAN'S integration into the China-

Russia Eurasian architecture is as complicated as it is consequential for economic and security relations across Eurasia. As Beijing and Moscow seek to advance their respective strategic objectives while cooperating within the Shanghai Cooperation Organization (SCO) framework, Iran's integration carries the potential to shift the strategic balance between the two.

Iran is also a liability for each Eurasian giant's wider strategic agenda in the Middle East. Shared interests in Southwest Asia incline Beijing and Moscow to cooperate in supporting Tehran, but also define the limits of that support as each endeavours to expand its influence. With the security architecture of the Persian Gulf now in flux, Beijing and Moscow have a unique opportunity to reorient both Iran and its regional rivals towards the China-Russia Eurasian architecture.

Iran has the world's second-largest natural gas reserves and the fourthlargest oil reserves. Unfettered Iranian hydrocarbon exports could reshape Eurasian geopolitics to China's benefit and Russia's detriment. Moscow is wary of Tehran jeopardising Russia's pre-eminence among Eurasian energy suppliers by redirecting energy flows, affecting the supply and demand balance.
Iran's strategic position at the heart of Eurasia's southern rim also makes it the geographic pivot in China's Belt and Road Initiative (BRI). Iran provides a crucial link for a ChinaEurope rail link that does not traverse Russian territory. China's current nonRussian option, the Trans-Caspian Corridor, uses the Baku-Tbilisi-Kars railway and requires ferrying cargo across the Caspian Sea from Central Asia to Azerbaijan. An Iranian rail link would offer a contiguous and more cost-effective solution.

In early 2016 the first China-Iran cargo train made its maiden journey from China's Zhejiang province to Iran in just 14 days, beating by two-thirds the time taken on the maritime route. Unlike the troubled China-Pakistan Economic Corridor (CPEC), a ChinaIran corridor would face fewer security and engineering challenges.

With its newly constructed deepsea port at Chabahar and rail links extending into Central Asia, Iran is also poised to become the hub of the International North-South Transit Corridor (INSTC), an Indian Ocean-to-Europe commercial route that would provide an alternative to Beijing's BRI architecture. Because this route is free of Beijing's involvement, Russia and India have engaged Iran as partners in the project. Moscow recently secured Iran's inclusion in the Russian-led Eurasian Economic Union (EaEU) that also includes Armenia, 


\section{ASIAN REVIEW: REGIONAL RIVALRIES}

Kazakhstan, Kyrgyzstan and Belarus.

Like Iran's EaEU membership, the INSTC contributes to Moscow's strategic imperative to preserve its influence over the South Caucasus and Caspian Sea basin through cooperation with Iran. RussianIranian cooperation is critical to blunting the eastward expansion of Turkish influence into the South Caucasus and Turkmenistan through Turkey's energy and transportation partnership with Azerbaijan. The China-to-Europe commercial transit route based on the Trans-Caspian Corridor needs to pass through Turkey, thus augmenting Ankara's influence in the wider Caspian basin region at Russia and Iran's expense.
Beijing seeks to incorporate Iran's commercial transit infrastructure into its BRI architecture. Iran's disappointment with India's adherence to US sanctions prompted Iran to suggest that Chabahar could be linked to CPEC's Gwadar port, 72 kilometres eastward on Pakistan's Arabian Sea coast. Using Iran's north-south rail links, China could create a vital vertical axis connecting Beijing's main East-West corridor to the Middle East and the Arabian Sea. Robust China-Iran cooperation would secure China's growing economic domination in Central Asia and further extend Chinese influence to the Caucasus and the Eastern Mediterranean.

Against this geopolitical backdrop,
Chinese President Xi Jinping's landmark visit to Tehran in January 2016 held out the possibility of reconfiguring strategic relations in Eurasia. It was prompted by the suspension of international sanctions against Iran under the Joint Comprehensive Plan of Action (JCPOA). Inking 17 agreements with Iran, China agreed to deepen its strategic relationship with the Islamic Republic over the course of 10 years, including raising the level of ChinaIran bilateral trade to US $\$ 600$ billion.

The geopolitical realities have turned out differently. The re-imposition of US sanctions on Iran after the United States' withdrawal from the JCPOA put a chill on China-

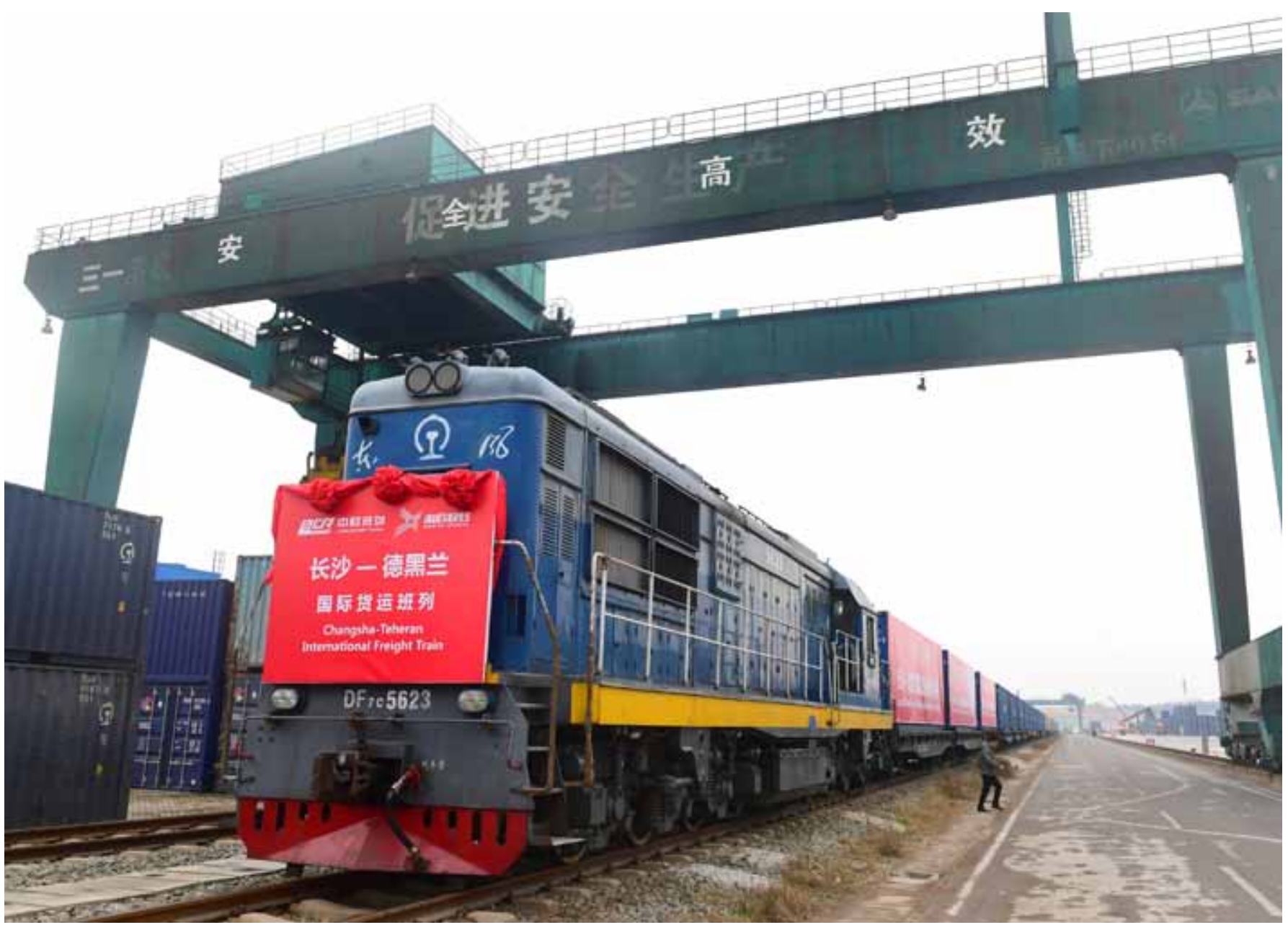

A China Railway Express train leaves Changsha, central China, for Tehran. China is keen to incorporate Iranian links into the Belt and Road infrastructure. 
Iran commercial relations. Despite Iran's geo-economic significance for Eurasian commercial connectivity, China is hesitant to embrace Iran-as indicated by Beijing's continued lack of enthusiasm for Iran's full membership to the Shanghai Cooperation

Organisation.

A full embrace of Iran would undermine Beijing's carefully balanced strategic position in the Middle East which enabled it to make important inroads into Saudi Arabia, the UAE and Egypt-Iran's principal regional rivals. Saudi Arabia is China's largest Middle Eastern trading partner and is second only to Russia as China's largest oil supplier. In 2017, Xi and Saudi Arabia's King Salman signed a US\$65 billion package of economic and trade agreements. This was followed in February 2019 by the signing of another package during Saudi Crown Prince Mohammed bin Salman's visit to Beijing.

China's relationship with Saudi Arabia has evolved from transactional cooperation to a 'comprehensive strategic partnership', aligning Saudi Arabia's interests with China's effort to create its self-declared 21st century Maritime Silk Road (MSR). The MSR is a maritime China-to-Europe transportation corridor consisting of a series of Chinese-built port installations extending westward across the Indian Ocean and via the Red Sea and Suez Canal to the now Chinese-owned port of Piraeus in Greece. After heavy Chinese investment, Piraeus is one of Europe's major seaports and a hub for Chinese goods to enter European markets.

China cannot comfortably tolerate Iran's proxy war against Saudi Arabia in Yemen because it endangers a critical segment of the MSR - the Gulf of Aden-Red Sea corridor. In January 2016, counter-balancing its opening to Tehran, Beijing declared its support for Yemen's efforts to defeat the Iranian-backed Houthi rebels. In 2016, China began constructing its own overseas base in Djibouti, across from Yemen between the Gulf of Aden and the Red Sea. Djibouti severed diplomatic relations with Tehran in 2016 and signed a security cooperation agreement with Riyadh, which then established its own base in the country.

Saudi Arabia and the UAE, with a base on Eritrea's Red Sea Coast, maintain a deep and active partnership with Egypt in protecting the Red Sea. China, also concerned about commercial transit through the Suez Canal, has invested billions of dollars in Egypt since Abdel Fatteh el-Sisi assumed Egypt's presidency in 2014. This includes Beijing's development of a port and industrial zone on Egypt's Red Sea coast.

Russia, which in 2018 signed a comprehensive strategic partnership treaty with Egypt, arguably enjoys an even closer relation with the Sisi government. It is engaged in a deep military partnership with Egypt, in addition to significant

China cannot comfortably tolerate Iran's proxy war against Saudi Arabia in Yemen because it endangers a critical segment of the Maritime Silk Road economic investments. Moscow is also strengthening its economic ties with Riyadh and cultivating a strategic relationship with the UAE.

The current crisis between Iran and its regional rivals has reached inflection point, particularly after the September 2019 attack on Saudi Arabia's Abqaiq oil processing plant, that can potentially change the strategic calculus of the Gulf states towards Eurasia's giants. Iran has announced that it will be conducting naval exercises with China and Russia. Neither Beijing nor Moscow will sacrifice its relations with Saudi Arabia, the UAE, and Egypt. Instead, they will likely present their trilateral naval cooperation with Iran as part of a new security framework to protect maritime commerce.

Absent the United States (the principal Saudi and Emirati security provider) and Europe providing an alternative by establishing a Persian Gulf maritime commerce protection force, the Arab Gulf states and Egypt could turn more towards the Eurasian framework as they seek Chinese and Russian auspices for brokering new security arrangements with Iran. Anything short of a complete security arrangement for Saudi Arabia and the UAE that is guaranteed by US military power will open the door for China and Russia to further reorient Iran and its Arab rivals towards the ChinaRussia Eurasian framework. EAFQ

Dr. Micha'el Tanchum is a senior associate fellow at the Austrian Institute for European and Security Studies (AIES), a fellow at the Truman Research Institute for the Advancement of Peace, the Hebrew University, Israel, and non-resident fellow at the Centre for Strategic Studies at Başkent University in Ankara, Turkey (BaşkentSAM). 


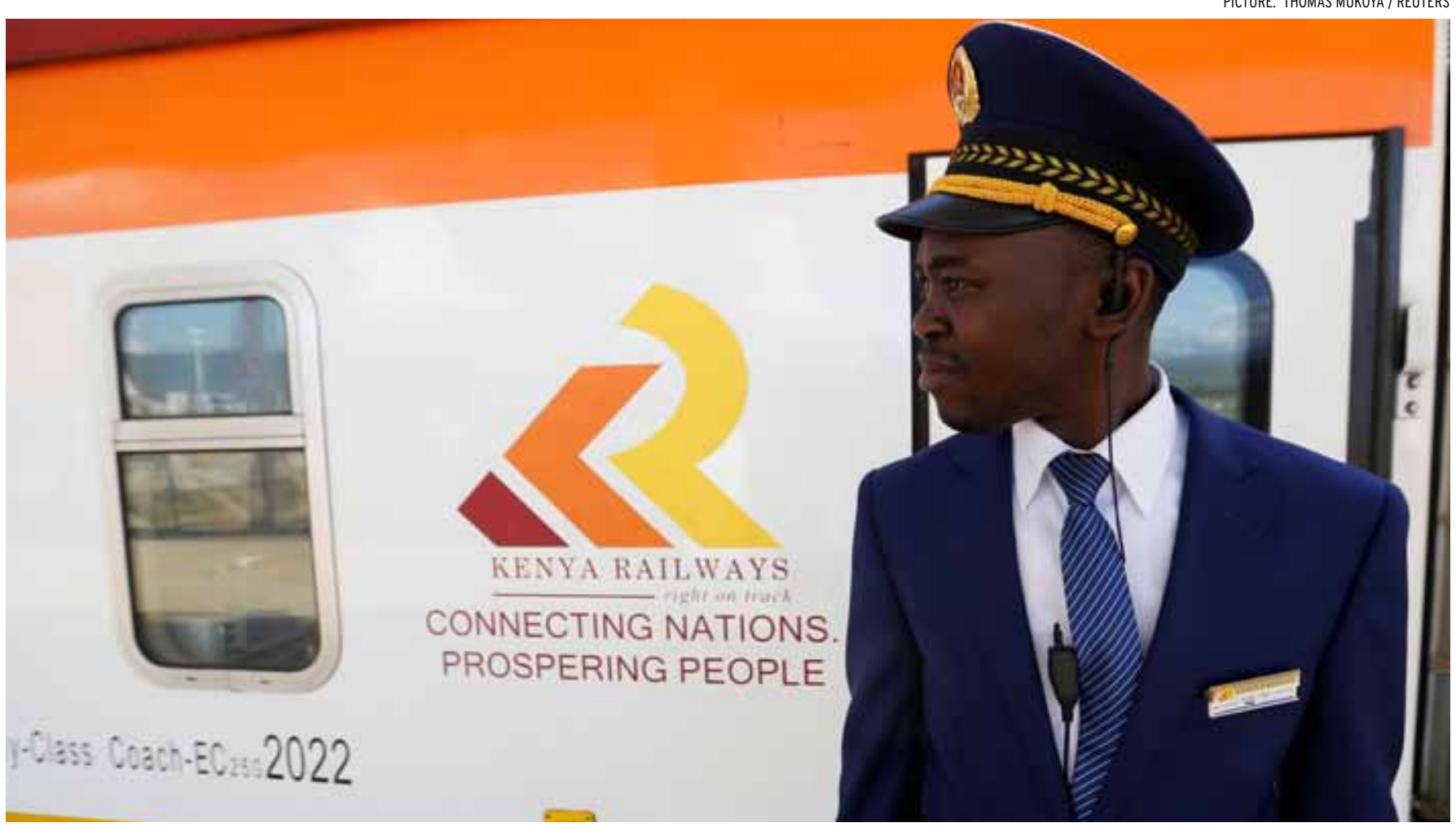

A Kenya Railways attendant stands before a Standard Gauge Railway carriage in Mai Mahiu. The railway was financed by the Chinese government.

\section{Economic statecraft and the revenge of the state}

DARREN J. LIM

$\mathbf{E}$ CONOMIC statecraft is typically defined as the use by governments of economic policy instruments to wield strategic influence over other nation-states. While this practice is as old as diplomacy itself, the increasing frequency with which it is being used today reflects growing assertiveness by governments of their expanding authority to intervene in markets to pursue broader national objectives. The 'states versus markets' debate has now firmly entered the realm of international relations, and 'states' appear to be winning.
The original 'states versus markets' debate was concerned with creating an optimal model of economic development for the postwar era. Was an economy overseen by a powerful interventionist state, and only conditionally open to international trade and capital flows, better suited to early- and mid-stage industrialisation than a lightly regulated and internationally open free market alternative?

While 'market' orthodoxy prevailed during the heyday of the Washington Consensus in the mid-1990s, the 'state' has slowly been clawing its way back since. Mainstream economic thinking now acknowledges that unfettered laissez-faire practices failed emerging markets, a view strengthened and broadened amid the rich-world imbalances that gave rise to the 2008-09 global financial crisis.

Beyond the acknowledged shortcomings of the market-driven approach, China today offers a distinct state-led alternative to Western models of economic development. The logic of the 'Beijing Consensus' is to employ capitalist forces as the engine of growth and poverty reduction, while the government retains the authority to intervene as it sees fit. This includes retaining operative ownership or control over industries of perceived strategic importance, such 
as telecommunications and energy.

China's economic structure is not unique historically-it shares many features with the developmentalist states of East Asia that enjoyed so much success in the postwar era. Now that China's economy rivals that of the United States in size, the Chinese Communist Party believes, and is arguing to the world, that its model of political order and economic development offers an attractive and perhaps superior model compared with that offered by the West.

$\mathbf{T}$ HIS means that Beijing's frequent use of economic statecraft in its foreign policy, where targeted market interventions-both carrots and sticks-are employed to further Beijing's strategic interests, is even more consequential in its impact on international relations. China's state-driven approach not only offers emerging market economies an appealing pathway to prosperity but also an apparently potent means of achieving influence on the global stage.

At a time when Beijing is perceived to be a strategic rival of Washington and great power competition is again a central feature of world politics, China's economic statecraft is expanding the definition and scope of the concept of national security. As Beijing and Washington come to perceive more and more economic domains-including trade, technology and education-as matters that touch upon broader national interests, each government is demonstrating an increasing willingness to intervene in markets and commercial transactions to advance its national security objectives.

US-China rivalry is normalising the use of economics as a matter of national security, giving rise to what has been described as a geoeconomic world order that other states will be impelled to follow. By this logic, economic statecraft is framed as 'geoeconomics': it is not simply about wielding narrow influence on a given issue, but directing economic activity towards grand strategy and the maximisation of national power.

Donald Trump's trade war is an obvious example of the state crimping markets in the name of a broader national interest. Yet it is Trump's recent edict to US companies to relocate operations from China to the United States that reveals a mindset much closer to the Chinese model than to neoliberal economic orthodoxies. On both the Republican and Democratic sides of politics, calls for an activist industrial policy are becoming more mainstream, further cementing a shift away from free markets both in the name of economic revitalisation and strategic competition with China.

The state-led approach is also receiving support from a third vector: the rise of populist, nationalist and/ or anti-establishment political movements across both the West and the developing world. These movements are steered by leaders who mobilise grievances wrought by globalisation, technological progress and social upheaval as justifications for radical policy agendas to overturn existing globalist and cosmopolitan orthodoxies.

These three forces-the perceived success of the Chinese model, the securitisation of economic policy amid great power rivalry, and the rise of anti-establishment politics in the West-are increasing both the attraction and legitimacy of greater state power over markets, one consequence being an expansion in the frequency and scope by which economic statecraft can be used.
To take one recent example: in July the Japanese government tightened controls on exports of three chemicals used in South Korea to manufacture semiconductors and smartphones. The Japanese government relied upon national security justifications, claiming concern that some of the materials could be converted for use in weapons. It is widely assumed, however, that the decision was actually related to a long-running dispute between the two countries over wartime compensation claims. Seoul retaliated by cancelling an intelligencesharing agreement with Tokyo, thereby fully bringing a political dispute from the economic into the security realm.

\section{A} S ARMED conflict declines in frequency and magnitude, perhaps one should celebrate the tendency for states to use non-violent means like economic statecraft to prosecute their political interests. Nevertheless, market interventions do not come without costs. More interventions will mean more market distortions and more uncertainty for businesses. This could have profound but as yet unpredictable impacts on global supply chains, which rely on the free flow of components across borders.

As national security pressures grow, governments will increasingly take defensive countermeasures to minimise their vulnerability to economic statecraft deployed by their strategic competitors, as we are seeing with the decoupling debate in the United States and concerns in Australia about overdependence on China. EAFQ

Darren J. Lim is a Senior Lecturer in International Relations at the School of Politics and International Relations, $A N U$. 


\section{HABITS OF COOPERATION}

\section{Why China-Japan economic exchanges override tensions}

AMY KING

I OR more than a century, close economic ties between China and Japan have developed in the absence of cooperative political and security relations. China and Japan offer evidence that cooperative political relations are not a necessary precondition for the flourishing of economic ties. But the relationship also demonstrates the limits of the thesis that close economic ties can mitigate key sources of bilateral insecurity or political tension.

The modern China-Japan trade relationship has its origins in war between the two countries. Following Japan's victory in the First SinoJapanese War (1894-95), Japan received a series of valuable but highly unequal economic rights in China: most-favoured-nation status, preferential treatment for Japanese goods and foreign investment rights for Japanese manufacturers. These economic rights created the foundation for a highly complementary economic relationship that endured over the intervening decades-alongside colonialism, during war, a Cold War divide, historical grievances, territorial disputes and contestation over the future of the US-led order in Asia.

Deep patterns of economic integration between China and Japan offer three critical lessons for thinking about the factors that might help to build habits of cooperation in Asia.

First, individual business people, often working in concert with

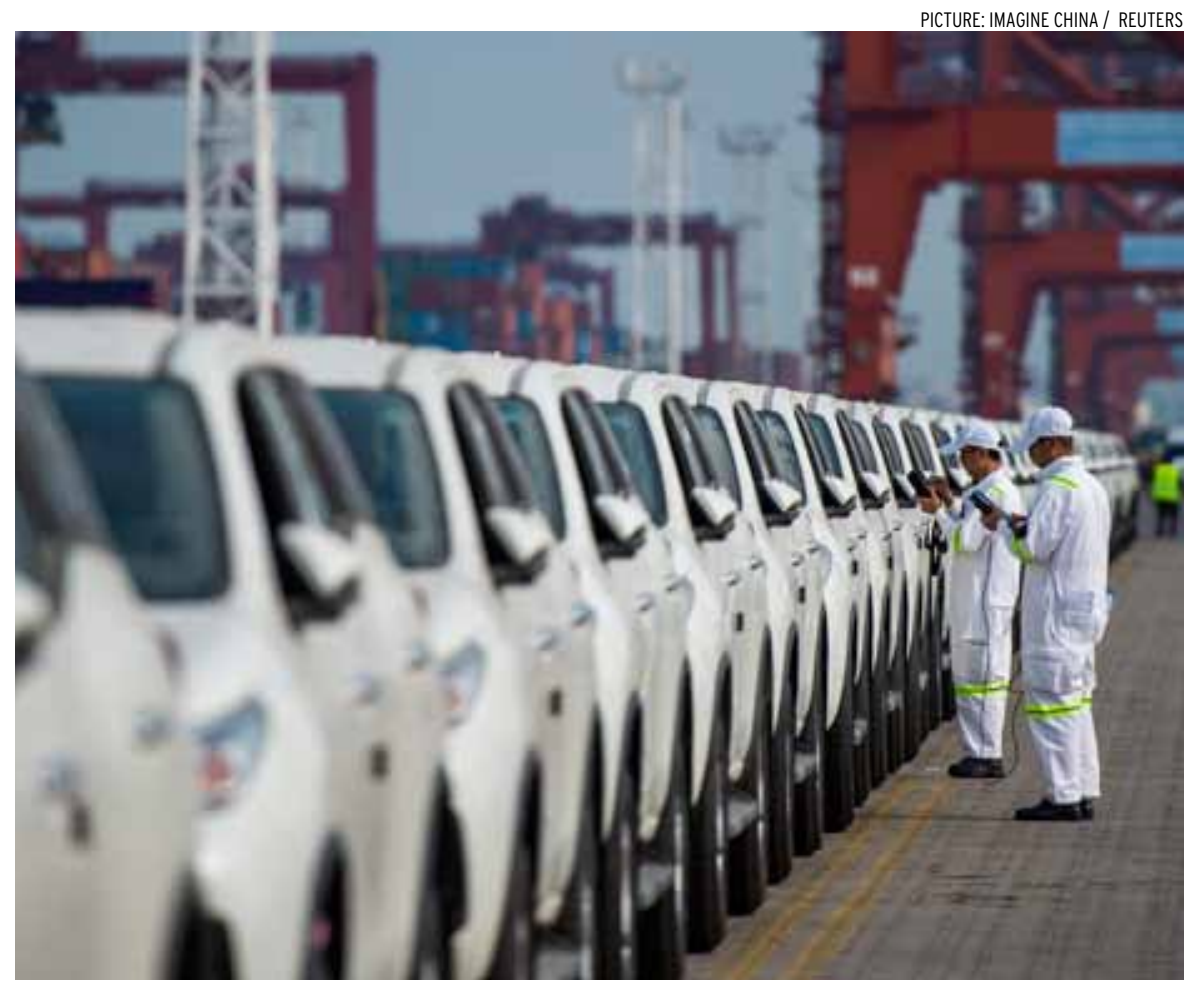

A line of parallel-import Toyota SUVs ready to roll at a port in Shenzhen city, Guangdong province. Japanese firms that are well integrated into Chinese society and business communities have been willing to maintain or increase their presence despite periodic difficulties.

government officials, have helped to sustain close economic ties between the two countries despite major changes in governing regimes, political systems and economic ideology over the past century. In the 1930s and 1940s, Japanese business leaders travelled to China as part of Japan's colonial empire in Manchuria. They established the industries that would extract Chinese soybeans and iron ore in exchange for Japanese machinery and steel.

In the 1950s and 1960s, these same Japanese were among those who sought to rekindle trading ties between Communist China and postwar Japan.
They would also develop government and business relationships that flourished following China's economic reforms in the 1970s and 1980s.

Successive generations of these early Japanese business leaders and firms now play a major role in explaining the persistence of Japanese investment in China-even as bilateral political relations have soured. As Kristin Vekasi has shown, Japanese firms with a high degree of familiarity with China's business and political environment are much less risk averse than firms which have limited experience in China. Japanese firms deeply integrated into Chinese society 
and business communities have been willing to maintain or increase their economic presence in China, even as they have experienced costly antiJapanese riots, boycotts and physical damage to their firms and products.

Second, flows of goods and people between China and Japan have been accompanied by flows of economic ideas. Japan has been a major influence on Chinese thinking about industrialled development, the role of science and technology in a modernising economy and linkages between the military and civilian halves of an industrialised economy. One of the most significant flows of ideas has occurred through foreign aid and development.

As China's largest-ever provider of official development assistance (ODA), Japan played a major role in shaping China's contemporary approaches to foreign aid and development, including its large-scale Belt and Road Initiative. Beginning in 1979, Japan was unique among the donor countries that provided bilateral loans to finance the building of roads, railways, ports and other major forms of infrastructure in China, as Marie Soderberg writes.

Japan's focus on infrastructure-led development stemmed from its own experience of economic development. Japan had a view that infrastructure would enable it to facilitate trade with, and extract natural resources from, recipient countries. Japanese firms also frequently won contracts to build large-scale infrastructure projects in China.

China's firsthand experience of Japanese ODA - and the hundreds of Chinese officials who worked closely with Japanese government agencies to administer infrastructure-led development in the 1980s and 1990shave shaped China's infrastructure- based development assistance as it shifted from a recipient to donor country.

Third, deep patterns of economic cooperation between China and Japan have created a separate sphere of regional economic activity that has often worked against the grain of the global order. During the first half of the Cold War, when global trading relations became divided into rival US-led and Soviet-led blocs, Japan and China continued to trade across Cold War lines.

Maintaining these trade tiesagainst the wishes of Japan's ally, the United States-was not easy in the absence of diplomatic relations, and given China's Soviet-style planned economy. But the persistence of China-Japan trade helped to chip away at US expectations that its allies would undertake wholesale economic containment of China. It also provided China with important economic alternatives to the Soviet Union and laid the foundations for supply chains that would later underpin a distinct East Asian economic order.

Japan and China continue to exhibit similar patterns of strengthened regional economic activity in the face of a fracturing global order. Since 2018, Japan and China have agreed

Ongoing economic

\section{cooperation between}

\section{China and Japan seeks}

to bring about greater

convergence in global

infrastructure investment to mechanisms that will facilitate joint investment in third-country infrastructure projects. Agencies such as the Japanese External Trade Organisation and China Council for the Promotion of International Trade are collaborating on China-Japan joint business development in Southeast Asia. The China Development Bank and Japan Bank for International Cooperation have agreed to common principles, initiated by Japan, to guide 'high quality' infrastructure investment.

At a time of heightened strategic rivalry between the United States and China, moves such as these complicate simplistic narratives seeking to pit 'Western' and 'Chinese' approaches to economic development against one another. Ongoing economic cooperation between China and Japan instead seeks to bring about greater convergence in global infrastructure investment. This bilateral economic activity should not be expected to ease the deep-seated political and security challenges in the China-Japan relationship. But the China-Japan infrastructure, investment and trade relationship serves as a critical example of how regional economic activity can resist the march toward economic decoupling or a 'new Cold War'.

Economic cooperation between Japan and China has become habituated in persistent flows of people, goods and ideas. These flows have their own independent momentum such that economic ties have been sustained throughout periods of bilateral political conflict, serving to weld a fragmenting global order. EAFQ

Amy King is a Senior Lecturer at the Strategic and Defence Studies Centre, ANU. 


\section{Is China a rogue investor?}

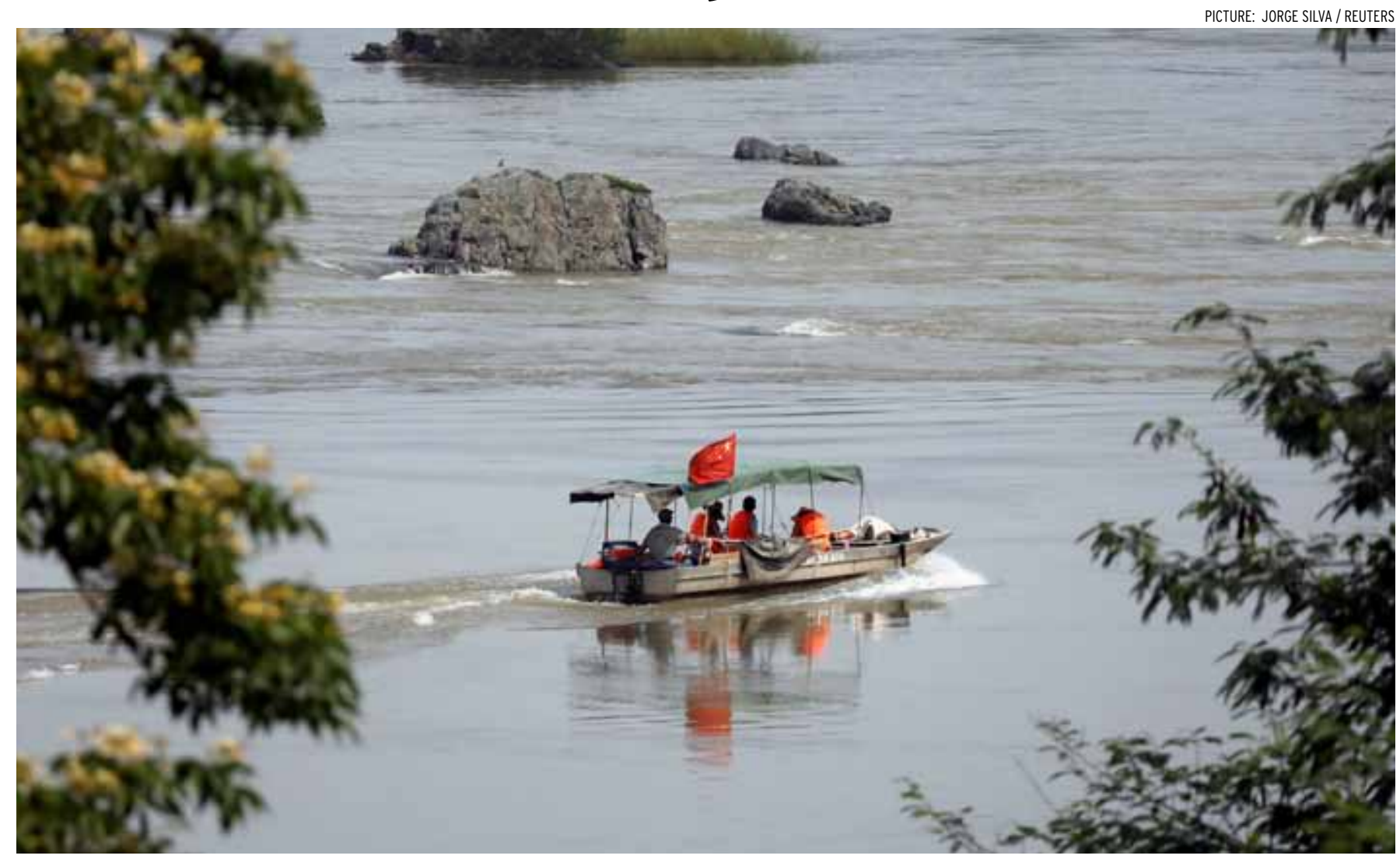

PICHAMON YEOPHANTONG

प HE Chinese don't want

friendship with people',

responded a well-known

environmental activist in Yangon

when asked about China's role in the

controversial, US\$3.6 billion Myitsone

hydropower project, the construction

of which was suspended in 2011 amid unprecedented grassroots opposition. Planned on the Irrawaddy River, the dam was touted as contributing to Myanmar's energy security and economic development. Yet its cited benefits were soon called into doubt: up to 90 per cent of the electricity to be produced was destined for China, while a leaked environmental impact assessment report revealed the many social and ecological problems posed

Chinese geologists surveying the Mekong River at the border between Laos and Thailand. Chinese firms have been involved in a number of hydropower projects in Southeast Asia.

by the dam. Alongside Chinese attempts to lobby for its resumption, protests demanding the Myitsone's cancellation continue to be staged locally.

For communities and activists seeking to resist large-scale Chinese investment projects, a 'Chinafied' future seems bleak as well as inevitable. Canberra's Pacific Step Up speaks to similar anxieties. Billed as a strategy to assist Pacific Island countries with meeting their needs, it serves the added purpose of checking Chinese money and influence in Australia's 'patch.' The strategy also feeds into broader concerns over the geostrategic and development implications of expanding Chinese economic power in the Asia-Pacific, with fears of Chinese 'debt-trap diplomacy' proving especially prevalent (Vanuatu's Luganville Wharf comes to mind).

Little hard evidence exists, however, to substantiate claims that Chinese loans and investment harbour debttrap or resource-seeking motives, or that China favours doing business with authoritarian regimes. Although Chinese companies can and do act irresponsibly, China is not a rogue investor.

This is a distinction worth making: whereas rogue investor, as derived from the 'rogue donor' trope, 
suggests predatory behaviour that stifles democratic governance and promotes autocratic tendencies in host countries, irresponsible conduct connotes ill-informed corporate practices that can stem from a failure to manage environmental, social and governance risks.

The main issue with Chinese money lies more with how it is being used than why. Consider the Southeast Asian case. Interviewing policymakers and activists in Cambodia, Laos, Myanmar and Vietnam, it is clear that 'China, Inc.' continues to be associated with a brand of extractivism with Chinese characteristics. Compared with Japanese-financed projects in the region that are popularly perceived as building, with superior skills and technology, vital connectivity infrastructure, Chinese projects are often viewed negatively as being of lower quality and geared towards exploiting the region's natural wealth to serve Chinese interests.

\section{$\mathbf{T}$} HE public opacity of Chinese ventures, combined with weak regulatory enforcement and systemic corruption in Southeast Asia, usually worsens the situation. Villagers affected by the SinoMyanmar oil and gas pipelines in Kyaukphyu reported, for example, how compensation money was informally handed out in see-through plastic bags. More recently, local officials from Laos' Houaphanh province have asked the national government to cancel a Chinese coal company's survey contract due to its failure to compensate villagers.

These problems coalesce with perceptions of the Chinese as focused on cultivating government-togovernment ties at the expense of local communities. Activists fighting against the Cheay Areng dam project decry the way that Cambodians were trapped in a 'win-win-lose' scenario, as China's state-owned Sinohydro sought to back a socially and environmentally destructive project-albeit one which would benefit the country's elites. Had the dam not been suspended (thanks to intense grassroots opposition), it would have paved the way for illegal logging and mining in surrounding areas, similar to what had happened around the Lower Sesan II dam.

Chinese-backed infrastructure development has similarly courted controversy. Hanoi's long-delayed Cat Linh-Hadong Metro Line, built by state-owned China Railway Sixth Group Co., Ltd. and developed in partnership with the Beijing Mass Transit Railway Operation Corporation, is a case in point. The project feeds into Vietnam's Railway Development Strategy, which prioritises the construction of urban rail infrastructure in Hanoi and Ho Chi Minh City. Yet despite having been scheduled for completion in 2013, at the time of writing, it is still unclear when operations will commence. Cost overruns and safety issues have also plagued the project's development. Initially its price tag was estimated at US\$552 million, with Chinese loans to cover US $\$ 419$ million. Costs soared and, soon enough, an additional loan of US\$250.6 million was needed from the China Exim Bank to finish the project. This led to further delays in the loan's disbursement. In Vietnamese social media, the project is mockingly compared with the accident-free, Japanese-backed metro line in Ho Chi Minh City.

But are Chinese companies that different from other investors operating in the region? Thai and Vietnamese private banks and companies, too, are known for investing in problematic infrastructure and agribusiness ventures. In Cambodia, Vietnamese agribusiness company Hoang Anu Gia Lai and Thai sugar giant Mitr Phol are both involved in protracted land disputes over their respective rubber and sugarcane plantations. Investigations into the Lao saddle dam's collapse at the Xe-Pian Xe-Namnoy hydropower project in 2018 revealed that South Korean SK Engineering \& Construction might have used substandard construction methods to lower costs. Australian involvement in contentious projects, such as Bougainville's Panguna copper mine, has likewise tarnished Australia's reputation in the Pacific.

\section{C} HINESE businesses are no more self-serving than their foreign counterparts. Even so, what these observations illustrate is the importance of host-country agency. Whether an investment project generates local benefits depends not only on the company involved but equally on the existence of political will to negotiate contracts transparently and enforce regulations. When a host government threatens to cancel a high-profile 'Belt and Road' project, as in the Malaysian rail link case, China will likely try to renegotiate to save face and prevent further loss. With Southeast Asia's infrastructure needs requiring around US $\$ 210$ billion in investment annually, it warrants note that the questionable projects cited here were primarily driven by the host governments themselves, rather than China.

Despite Xi Jinping's tighter regulation of private firms, and the close relationship between the central government and state-owned enterprises (SOEs), Chinese companies have retained their autonomy. Chinese SOEs, in 
particular, are becoming less reliant on financing from the Chinese state. Having transformed from contractors to become investors and operators as well, they are now engaging more in public-private partnerships, joint ventures, and 'third-party market cooperation'.

Today, the profit motive of Chinese businesses is all the more pronounced-just as the reputational costs of irresponsible investment gain greater prominence in their commercial calculations.

Because the more capitalised markets are too crowded, Chinese companies 'going global' say that they have little choice but to invest in 'riskier' countries. As many will point out, however, they would rather not operate in corrupt political systems. This is due to the increased chances of project delays and cost overruns from, for instance, bribery or political instability. In a worst-case scenario, the security of Chinese workers could be jeopardised, anti-China fervour stoked, and a project cancelled without notice. Indeed, the Myitsone dam's suspension, which had then cost China Power Investment Corporation US\$800 million, was a turning-point in reinvigorating debates within Chinese business and policy circles on the importance of corporate social responsibility, stakeholder engagement and political risk.

Wider recognition among Chinese firms and the central government of the negative impacts of irresponsible 'business-as-usual' practices, along with the need for reform, is reflected in the substantial and still-growing body of regulations and guidelines for managing SOE conduct overseas. It is also evident from the Belt and Road Initiative's Green Investment Principles and the Asian Infrastructure
Investment Bank's policy frameworks. Now more so than before, there are signs that Chinese companies are willing to engage with local and international NGOs. China Datang Overseas Investment Corporation, for one, has recently opened up to dialogue with Thai civil society on the impacts of the Pak Beng dam on the Mekong River.

Of course, there will always be irresponsible Chinese businesses. But rather than going rogue, China and its major companies are increasingly concerned with their global image. Risking reputation may no longer be a risk worth taking. EAFQ

Pichamon Yeophantong is an Australian Research Council DECRA Fellow and Senior Lecturer in the School of Humanities and Social Sciences, UNSW Canberra at the Australian Defence Force Academy.

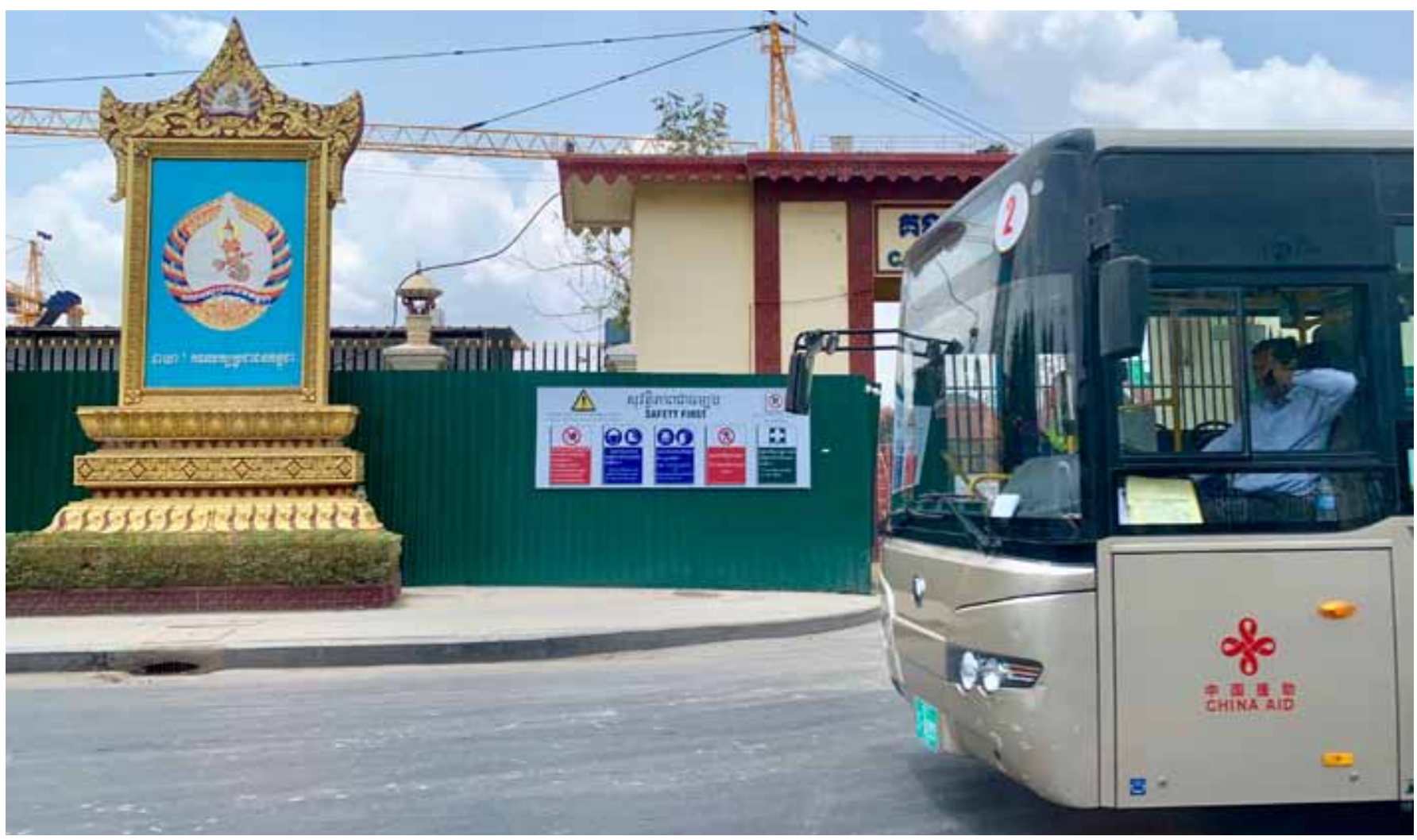

Significant presence: A China Aid bus passes in front of the Cambodian People's Party headquarters, then under construction in Phnom Penh, in March 2019. 


\section{Weaponised interdependence and Japan's private sector}

KRISTIN VEKASI

ROM trade barriers to financial
sanctions, it is more and more common to see economic interdependence deployed for political goals. The United States uses its control of global financial networks to implement its economic sanctions policy and has used trade restrictions to restrict Chinese competitors' access to US-based technology. China is said to have used this strategy against Japanese firms with the rare earth issue in 2010 and against high visibility, consumer-facing industries following Japan's nationalisation of disputed maritime territories in 2012.

South Korea experienced similar treatment from China following deployment of the Terminal High Altitude Area Defense missile systems, with retaliation against the tourism industry. Japan is currently said to be using similarly coercive tactics against South Korea. Japan has put new export restrictions on high-tech sectors central to the South Korean economy where that country is asymmetrically dependent on Japan for key supplies. This is an escalation of a dispute rooted in contested history that was reignited in 2018 when the South Korean High Court ruled that two Japanese companies were responsible for wartime forced labour reparations.

This type of economic coercion, dubbed 'weaponised interdependence,' affects multinational firms first and foremost-entities that are often removed from the geopolitical issue that starts such coercion. These

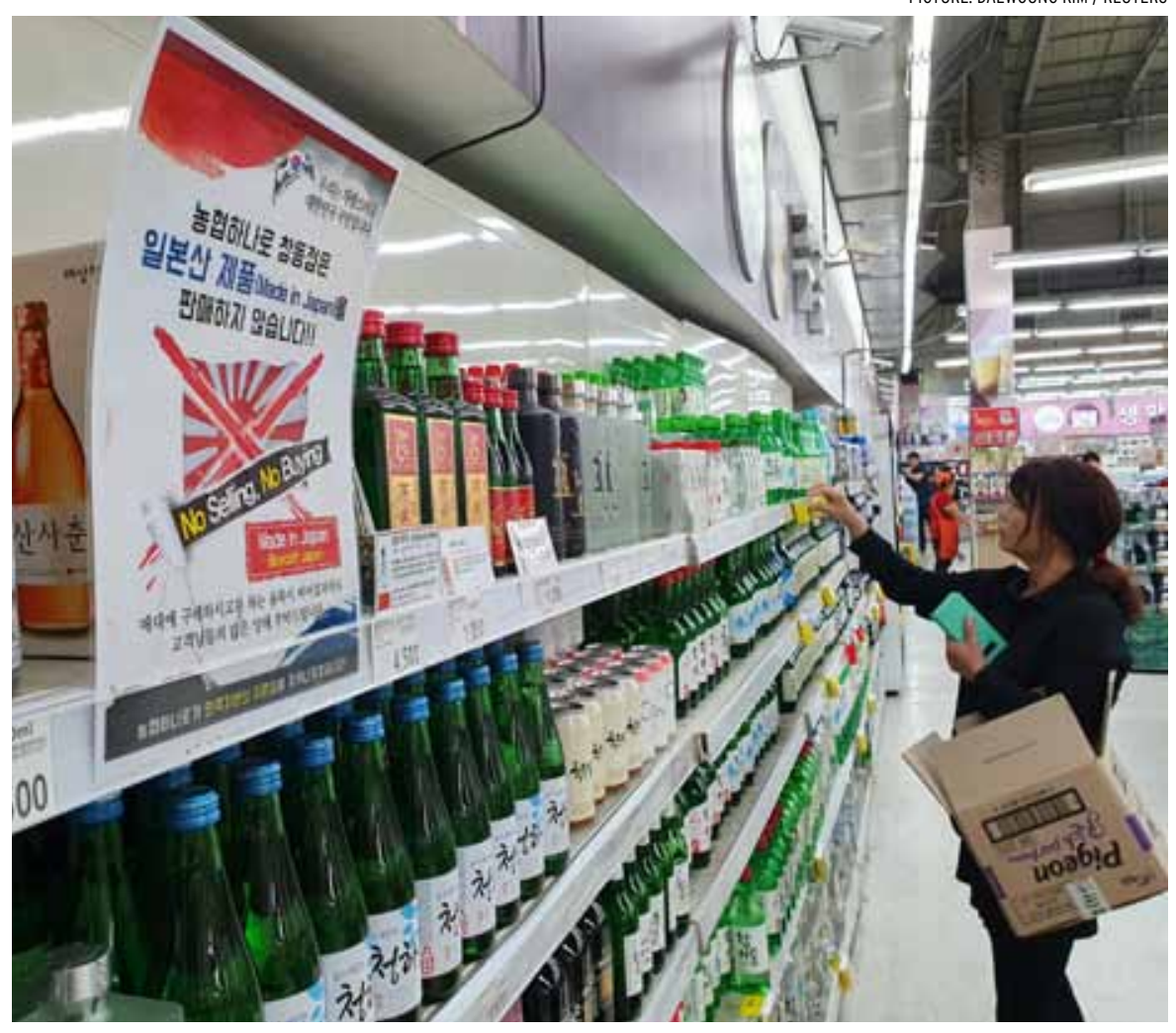

Economic coercion: A shopper browses in a Seoul supermarket in July 2019 where a notice campaigning for boycott of Japanese products proclaims 'We don't sell Japanese products'.

companies become potential targets of the state as well as angry consumers and civil society.

Toyota was not the driving force behind the Japanese government nationalising the disputed Senkaku/ Diaoyu island chain. Yet their auto production and trade with China was severely damaged. Japanesebranded vehicles were smashed in the streets and production fell in Japan's joint ventures. While South Korean companies were not directly responsible for the 2018 court decision, the export restrictions curtail their ability to manufacture smart phones, semiconductors and other products.

Japanese companies have managed country-of-origin risks well before the current era of so called weaponised interdependence, albeit with mixed success. The cold welcome received by Japanese nationals in Southeast Asia in the 1960s and 1970s and nationalist 'Japan bashing' in the United States in the 1980s and 1990s resemble contemporary conflicts. Management strategies include diversifying throughout the Asia Pacific, engaging with the host society through public diplomacy or simply waiting out the 
crisis while minimising damage.

Diversification is a potent riskmanagement tool. The 'China-plusone' strategy involves maintaining a subsidiary in China while opening a new subsidiary in a third country either to minimise production disruptions or take advantage of changing market conditions. While China-plus-one is not solely a response to economic coercion or backlash, Japanese firms state that protests and business restrictions push them to fast-track their plans to diversify.

Many firms need to stay on the mainland in order to keep market access: total exit would be devastating to their business models. Yet, with the increasing costs of doing business in China, shifting manufacturing production to a less-expensive country in Southeast Asia is an attractive option.

Following the nationalisation of the Senkaku/Diaoyu islands in 2012, China-plus-one style diversification became more prevalent, particularly for the sectors targeted by boycotts, protest and state sanctions. In 2012, Japanese creation of subsidiaries in the combined 'plus one' countries overtook subsidiary creation in China for the first time in decades. Controlling for wages, exchange rates and other fundamental macroeconomic indicators, China lost new assets and employees from Japanese companies to Southeast Asia following the 2012 crisis.

Exiting the market-even partially-is not always an option for firms. Costs of exit may be too high or direct access to Chinese consumers may be the raison d'etre of the company's Chinese subsidiary. These firms need to manage the risks they face locally with an eye for future consumer relations and market access. Companies do so by relying on professional organisations to keep employees out of harm's way, nurturing ties to local officials and business partners and maintaining a low profile. But this quiet approach is sometimes not enough.

Japanese firms also actively engage with the society of the host country with the aim of improving person-toperson relations in the long run. Many of these engagement activities take the form of corporate social responsibility, such as a Hayao Miyazaki exhibition in China and donations to the Japanese Chamber of Commerce and Industry to bring Chinese college students on study tours to Japan.

Even patient waiting takes a degree of work to maintain a business presence abroad in the face of overt or even perceived hostility from a host society. In China, Japanese firms work with local and national officials and security forces to protect their interests. When there is no direct danger to either product or supply chain, firms will typically choose to wait out incidences of geopolitical risk.

These tactics have been effective for Japanese companies historically. Following the 1974 Malari Incident in Indonesia, a combination of

When there is no direct danger to either product or supply chain, firms will typically choose to wait out incidences of geopolitical risk economic engagement and 'heartto-heart' diplomacy through the Fukuda Doctrine improved the business environment for Japanese multinationals. Southeast Asia is no longer seen as a place to manage risks from anti-Japanese sentiment but rather a place to go to flee it. AntiJapanese sentiment in the United States has also been soothed by Japanese investment, job opportunities and cultural engagement.

The strategies of Japanese firms are more likely to be successful when the Japanese government is not using weaponised interdependence against its trade partners. With the Abe government's escalation against South Korea, business actors and economic relationships have been drawn straight into the crosshairs of historical disputes-an area previously insulated from politics.

Unlike relations with China, where consumer behaviour and trade and tourism policy are more frequently used as tools of economic coercion, Japan-South Korea relations had a clearer separation between politics and economics. This separation seems to have ended and both Japanese and South Korean companies must now pursue the same risk-management tactics. Yet the foundation of cooperation between Japanese and South Korean business communities is strong and should provide more opportunities for private sector leadership in resolving geopolitical conflict. EAFQ

Kristin Vekasi is an Assistant Professor in the Department of Political Science and School of Policy and International Affairs at the University of Maine. She is the author of Risk Management Strategies of Japanese Firms in China: Political Crisis and Multinational Firms (Routledge 2019). 


\section{Japan-ROK dispute: weaponising trade?}

KAZUTO SUZUKI

J APAN'S decision to remove South Korea's so-called 'white country' status and shift the licensing arrangement of three chemical products critical to that country's semiconductor industry is seen as a 'weaponisation of trade' by some, and a 'Trumpianisation of the Abe administration' by others. But neither characterisation is strictly correct, even though it might seem so.

The decision to change the licensing arrangement for the three productshydrogen fluoride, photoresist and fluorinated polyimide-was made at a volatile time in Japan-South Korea relations. It came after the administration of President Moon Jae-in, late in 2018, terminated the foundation that had been created with the formal agreement in 2015 to compensate 'comfort women' for the abuses suffered under Japanese occupation. The agreement stated that it settled the question of compensation 'finally and irreversibly', but President Moon reversed that decision.

Then, also late in 2018, the Supreme Court of South Korea ruled that Japanese companies should compensate victims of forced labour, despite the 1965 Japan-South Korea Claims Settlement Agreement. The Japanese government regarded this ruling as a violation of international law and insisted the South Korean government do something to override it. But the Moon administration maintained that it could not intervene in the court's decision, instead offering to share the compensation between Japan and South Korea. According to the Japanese government, this would jeopardise the '1965 regime' and the foundation of the Japan-South Korea relationship.

Subsequently, when the Japanese government decided to change the export control regulations on the chemical products and remove South Korea's 'white country' status, Prime Minister Abe, Chief Cabinet Secretary Yoshihide Suga and Minister for Economy, Trade and Industry Hiroshige Seko said on the record that they had come to the decision because they had lost confidence in South Korea.

It was interpreted that the forced labour issue had influenced their decision, so it was only natural that the South Korean government and its people saw this as retaliation. But the Japanese government argues that the action aimed simply to change South Korea's export control system and practices, which had not been implemented as the Japanese

\section{The South Korean}

government ... regards

Japan's actions as a

retaliatory response to

the 'forced labour' ruling government expected. Japan argued that South Korea's preferential treatment under Japan's export licensing arrangements should be withdrawn from 'white' to normal status to ensure that Japanese products were not transferred to destinations of concern.

This action should not be regarded as 'weaponisation' or economic statecraft because it does not aim to change South Korea's view on the forced labour issue. Weaponisation of trade means that one country forces its political will upon another country by using restrictive trade measures-retaliatory tariffs under the World Trade Organization (WTO) or sanctions on Iran to usher it to the negotiating table are good examples.

However, Japan's decision to change export control regulations had a similar impact to the weaponisation of trade because it targeted three 'choke point items' of critical importance to South Korea, moving the chemical products from general licence to individual licence treatment. If Japan decided to restrict or embargo these items, it would effectively choke South Korea's semiconductor industry.

Japan has not restricted or embargoed these items. It has issued licences on hydrogen fluoride and photoresist already, while an export licence for fluorinated polyimide was granted in September. Although the export volume is still small and it took time to assess individual exports, all three items continue to be exported to South Korea.

Japan has thus not used trade as a 
weapon to corner the South Korean semiconductor industry. Its actions were driven by genuine concern that South Korea's export controls were not being implemented appropriately, and that Japanese exports to South Korea were being diverted to end-users in China as well as countries in the Middle East and Africa.

Japan shifted these three items from a general licence to an individual licence because it needs to examine the end-users and end-use of these items individually. As long as the end-users are legitimate, the Japanese government is continuing to issue licences. The South Korean government sees it differently. It regards Japan's actions as a retaliatory response to the 'forced labour' ruling that deliberately targets the choke point items. South Korea took the issue to the WTO General Council, blaming Japan for distorting free trade principles. It also removed Japan from its preferential export licensing country list (it seems that South Korea is shooting its own foot because it is doing exactly the same thing for which it blames Japan for distorting free trade).

Since Japan's actions were within the framework of a national export control regime, it appears unlikely that they will be considered a violation of WTO rules. South Korea upped the ante, deciding to terminate the General Security of Military Information Agreement (GSOMIA) with Japan.

This decision presents a challenge to both countries. The sour relationship between them is rooted in historical grievances. The overall relationship has thus far been insulated from historical issues because of the importance of the bilateral economic and security relationship.

The decision to terminate GSOMIA

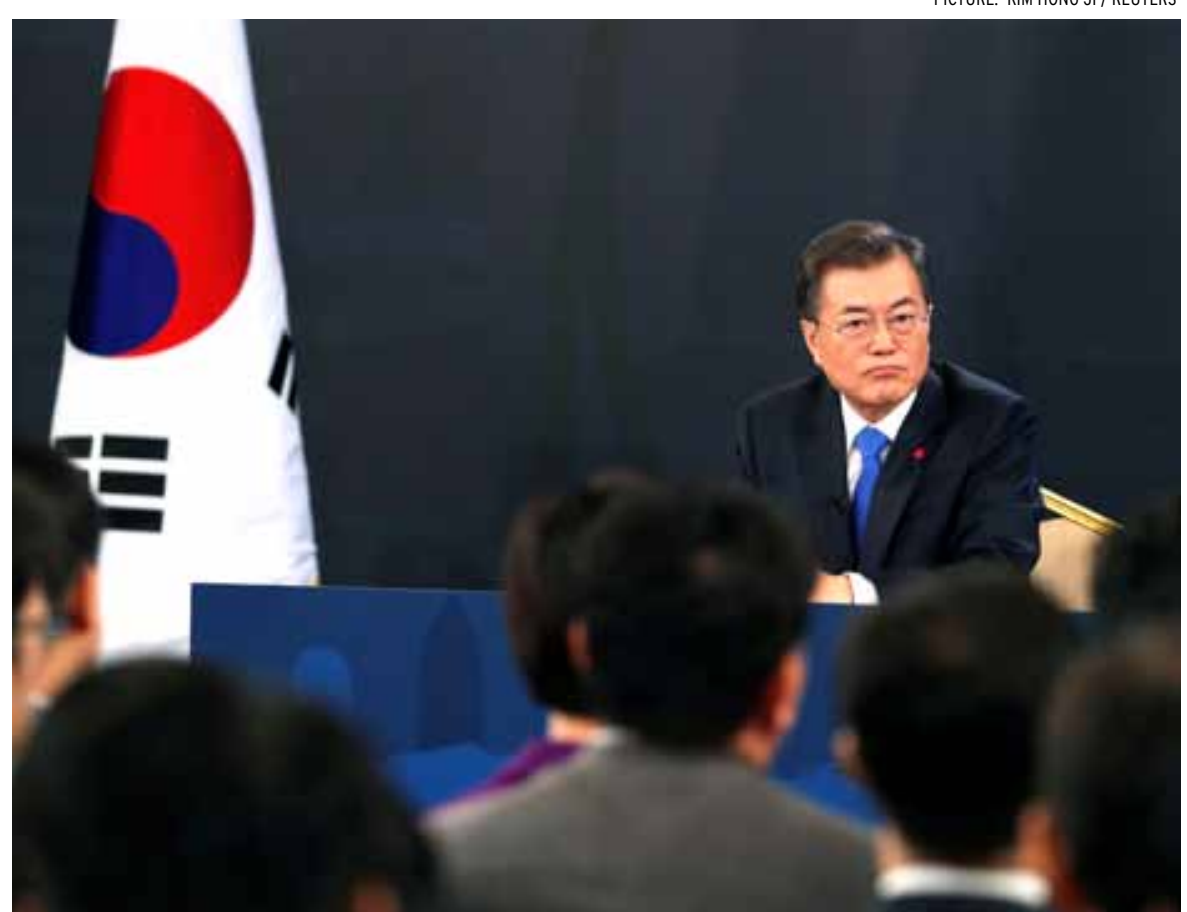

South Korean President Moon Jae-in at a news conference at the Presidential Blue House in Seoul in January 2018. His administration's decision later that year to terminate the foundation set up to compensate 'comfort women' helped to destabilise relations between Japan and South Korea.

linked the historical issues to issues of security. Though Japan shares some of the blame for failing to address the past, Tokyo believed security to be outside the scope of bilateral historical spats-particularly since North Korean nuclear and missile activities are increasingly threaten both Japan and South Korea.

The decision also linked the bilateral relationship to the trilateral security cooperation framework with the United States. GSOMIA was concluded in 2016 under pressure from the United States to strengthen Japan-South Korea intelligence cooperation in response to the growing North Korean threat. Ending GSOMIA suggests that South Korea no longer wants to cooperate on this issue under this framework.

The Moon administration is persuaded that North and South can achieve peace and autonomy for all Korean people. Most Japanese view this as over-optimistic, but the Moon administration seems seriously to believe that it can achieve more autonomy from the influence of Japan and the US if North and South are getting along and working together.

It is hard to predict how this JapanSouth Korea conflict might be settled. But it is important to remember that Japan has not taken the position to weaponise trade. If South Korea wishes to restore its status on Japan's 'white country' list, it does not have to appeal to the WTO or terminate the GSOMIA. All it needs to do is review the implementation of its export control regulations and, in consultation with Japan, strengthen its institutions by, for example, increasing the number of export licensing and law-enforcement officials. EAFQ

Kazuto Suzuki is a Professor in the Faculty of Public Policy, Hokkaido University, Sapporo. 


\section{Breaking the North Korean nuclear stalemate}

\section{CHUNG-IN MOON}

\section{A} ROLLERCOASTER pattern of crises and peace has characterised the Korean peninsula for the past three years. In 2017, anxieties were heightened after North Korea conducted its sixth nuclear test in September and test-fired 15 ballistic missiles-including a Hwasong-15, an ICBM-in November. Tensions worsened when the Trump administration responded with rhetoric about 'fire and fury'.

There was a dramatic reversal in 2018. The Pyeongchang Winter Olympics in February led to a series of summits-the Panmunjom summit in April, the first North Korea-US summit in Singapore in June, and the Pyongyang summit in September. They opened new possibilities for peace by increasing the chance of a cordial settlement of the North Korean nuclear quandary. All three summits underscored an improvement of bilateral relations, commitment to a lasting peace regime in Korea and pledges to complete denuclearisation of the peninsula. Most Koreans strongly believed that peace was near.

This optimism was shattered when the Hanoi summit between North Korean Chairman Kim Jongun and US President Donald Trump in February 2019 failed to produce any tangible outcome. In Hanoi, the United States proposed a deal under which North Korea would first dismantle nuclear and biochemical weapons and missiles. In return the United States promised a bright future

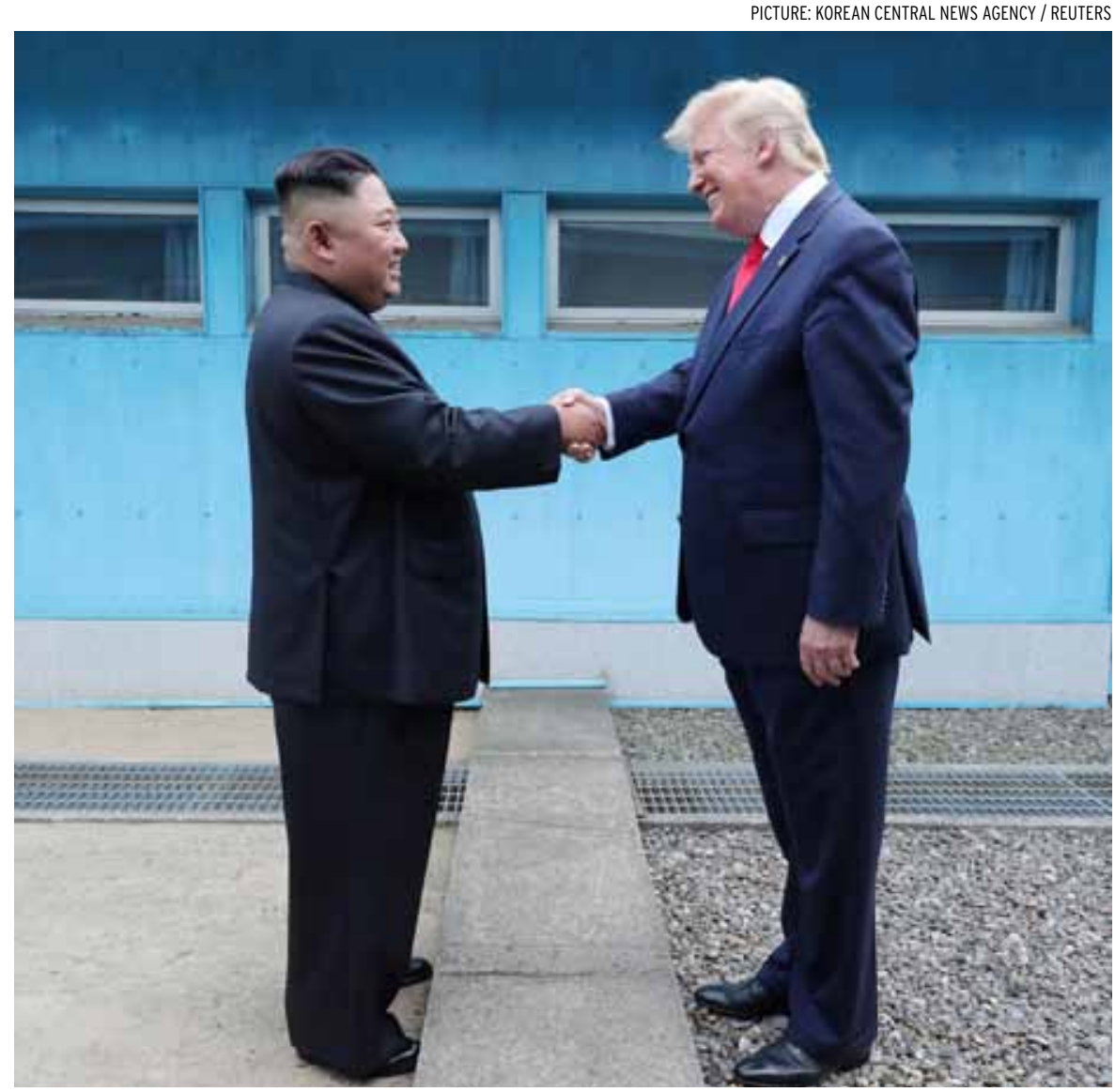

US President Donald Trump shakes hands with North Korean leader Kim Jong-un at Panmunjom, in the demilitarized zone separating the two Koreas, on 30 June 2019. A substantial gap remains between the two sides, and better relations may depend on both parties shifting from their entrenched positions.

for the North Korean economy.

But North Korea rejected the offer, instead adhering to the principle of incremental simultaneous exchange framed around 'action for action'. It counter-offered the final and complete dismantling of all nuclear facilities in Yongbyon while demanding the partial relaxation of five UN Security Council sanctions that have affected its civilian economy since 2016. North Korea's proposal was concrete, and it was desperate to make a deal. But the gap between the two sides was huge, and the summit broke down. Pyongyang suffered much from the Hanoi trauma, which severely strained both US-North Korean and inter-Korean relations.

A surprising Trump-Kim meeting in Panmunjom in June 2019 opened another window of opportunity. As both leaders agreed, US-North Korea working-level talks were held in Stockholm in October. But assessments of the talks differed. 
North Korean representative Kim Myong-gil declared that the talks failed because the United States came without a new approach, and it would be 'sickening' to have further discussions. The United States refuted this in a press release, stating that it had 'brought creative ideas and had good discussions.' The United States also accepted an invitation from the Swedish government to attend another round of talks with North Korea.

What went wrong in Stockholm? There may have been a hostile protocol gesture by North Korea. Trump's earlier rejection of Kim's proposal on the Yongbyon deal and the abrupt cancellation of the planned luncheon in Hanoi was a great insult to North Korea's supreme leader. A retaliatory gesture might have been calculated to repay the Hanoi humiliation. Such protocol retaliation is not uncommon in Pyongyang's diplomatic behaviour.

The scope of denuclearisation must have been another contentious issue. According to several reliable sources, including a Yomiuri Shimbun report, the United States demanded North Korea's commitment to transfer all nuclear weapons, materials and ICBMs to the United States and dismantle all facilities related to the production of nuclear or biochemical weapons and ballistic missiles. Complete dismantling of all nuclear facilities in Yongbyon, declaration of and commitment to the elimination of clandestine nuclear facilities elsewhere, and freezing all nuclear activities were also required. Such demands were unacceptable to North Korea. At most, Pyongyang could have counter-offered the Yongbyon card raised at the Hanoi summit.

Divergent expectations on corresponding measures were also a source of friction. The United States reportedly offered temporary relief from the export ban on coal and textiles, resumption of humanitarian assistance, and the adoption of a declaration to end the Korean War. It was also rumoured that the United States showed a blueprint for the development of Galma tourist complex-Kim's signature projectwith a plan to mobilise international capital. Pyongyang rejected them outright by arguing that the United States had not yet even reciprocated North Korea's goodwill efforts such as a freeze on nuclear and ICBM tests since 2018.

North Korea announced in October 2019 that it was not interested in returning to the negotiating table unless 'the United States takes substantial steps to make complete and irreversible withdrawal of the hostile policy' Pyongyang does not want small concessions, but a major one involving the end of enmity through diplomatic normalisation and lifting sanctions.

The gap between Pyongyang and Washington is huge. Both states need to change the negotiation pattern of 'giving less and taking more'. Both should be willing to make concessions to reach a compromise.

Trust-building seems most essential

Pyongyang does not want

small concessions, but a major one involving the end of enmity through diplomatic normalisation and lifting sanctions in this regard. Trust can be built only on the basis of success stories, no matter how small they are. Pyongyang can invite international inspectors to the demolished Punggye-ri test site, dismantle the missile engine test facility and launching pad in Tongchang-ri, eliminate all nuclear facilities in Yongbyon, and declare and commit to dismantle additional hidden nuclear facilities. The United States should reciprocate by offering an exchange of liaison offices, suspension of joint military exercises, peace accord negotiations, and a partial relaxation of existing sanctionsincluding the resumption of Kaesong Industrial Complex and Mount Kumgang tourist project.

Only then can a comprehensive agreement on complete and verifiable denuclearisation in exchange for complete and irreversible withdrawal of hostile policies be reached, along with a concrete roadmap and timetable. The rhetoric of promising 'a brighter future for the North Korean economy' cannot move Pyongyang. Security assurances such as diplomatic normalisation and non-aggression treaties should be presented first, rather than at the end of negotiations. And it seems highly unlikely that North Korea will make any significant concessions without corresponding measures on sanctions relief.

Reaching such compromise will not be easy amid Trump's impending impeachment process and Kim's immense domestic disappointment. But the strong political will of both leaders is cause for optimism.

Chung-in Moon is Distinguished University Professor, Yonsei University, and Vice Chairman and Executive Director, Asia-Pacific Leadership Network for Nuclear Non-proliferation and Disarmament. 


\section{Australia, Asia and the Pacific As a region we are}
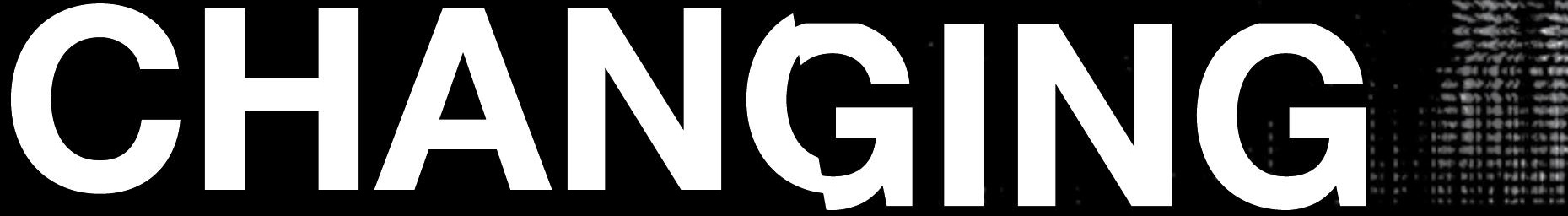

We see this in our people, politics, economies, environment, security and technology.

Since the Australian National University was established we have worked to understand our region, its challenges and its opportunities.

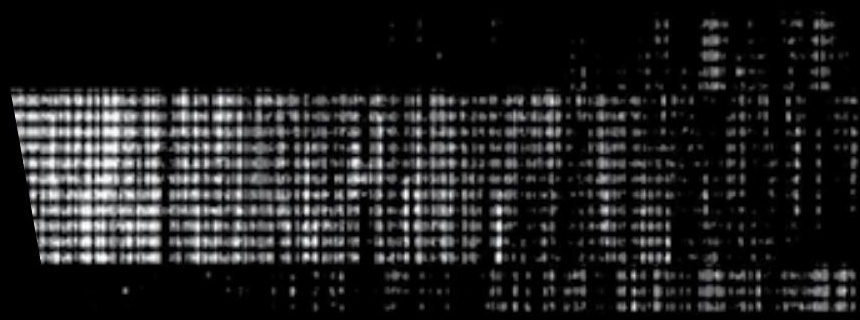

Today we are thinking differently, posing critical questions and generating nuanced perspectives.

We are working in communities to tell their stories.

We are engaging with policy makers to translate evidence into practical solutions.

And we are supporting business leaders to achieve better outcomes.

You too can be part of our region's changing future.

Connect with us at the Australian National University. ANU College of Asia and the Pacific.

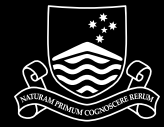

Australian National University 